\title{
Tongue-Tied in the Market: The Relevance of Contract Law to Racial-Language Minorities
}

\author{
Julian S. Lim $\dagger$
}

I want to hear the voices that represent different ways of living and knowing, particularly those ways that come out of the culture of the historically subordinated. I want to hear as well the literal voices of difference-differences in language, accent, cadence, and sound that have made the streets of the North Ameriean cities I love vibrant and alive. I ask that we nurture these voices and keep them from fading. My urgency in this quest is tied to my belief that it is what we must do, as a nation, to save our national soul. ${ }^{1}$

\section{INTRODUCTION}

When the Framers of the Constitution articulated the country's democratic vision in the motto "E Pluribus Unum,"2 they offered a maxim for reaffirming and celcbrating the cultural and linguistic diversity of its immigrant populations. Today, however, the promise secms largely empty, and the voice recognized by the institutions of this country speaks primarily one language: English. English is the language of our schools, our workplaces, our government buildings, our hospitals, and our marketplace. English is everywhere.

As a doorway to social inclusion, English plays a pivotal role in all areas of work, recreation, and civic life. Yet many U.S. residents are not native English speakers. A significant proportion of the population comes from non-English-speaking lands-predominantly from Latin America and

Copyright (C) 2003 California Law Review, Inc. California Law Review, Inc. (CLR) is a California nonprofit corporation. CLR and the authors are solely responsible for the content of their publications.

$\dagger \quad$ J.D. Candidate, School of Law, University of California, Berkeley (Boalt Hall), 2003. I would like to thank Professor lan Haney-López for his direction and support during the writing of this Comment, as well as Professors Norm Spaulding and James Gordley, who commented generously on earlier drafts. My husband helped me work through the various versions of the Comment to the end, often staying up late to keep me company, and I am indebted to him - thank you PJS. Lastly, I would like to thank my family for their continuous support and enthusiasm.

I. Mari J. Matsuda, Voices of America: Accent, Antidiscrimination Law, and a Jurisprudence for the Last Reconstruction, I00 YALE L.J. 1329, 1333 (199 I).

2. See Juan F. Perea, Demography and Distrust: An Essay on American Languages, Cultural Pluralism, and Official English, 77 MinN. L. Rev. 269, 275 (1992). 
from Asia. ${ }^{3}$ Although Spanish- and Asian-language-speaking immigrants have every incentive to learn and master the English language, fluency takes time and education. These resources often may not be readily available to new immigrants. It would be ideal if immigrants could swiftly and effortlessly incorporate themselves into society, for then they could better participate in various civic activities, contribute more to the economy and the market, and enjoy more fully the accompanying benefits and privileges. Immigrants do become employees, consumers, patients, property owners, and businessmen. Notwithstanding her level of fluency in the English language, the immigrant plays an integral part in the American economy as a worker or a consumer, and fairness should therefore require equal opportunity and just dealings in those areas.

The actual experiences of most language minorities, however, indicate otherwise. Most of the Spanish- and Asian-language-speaking members of this country face challenges to their participation, if not to their mere presence, simply because they cannot speak English fluently. ${ }^{4}$ For examples, we need look no further than the dishonest actions occurring in the marketplace, ranging from telemarketing fraud to deceptive home-solicitation sales to deceptive car-lot practices. ${ }^{5}$ Continued immigration assures the presence in the U.S. marketplace of millions of monolingual Spanish- and Asian-language-speaking consumers, and thus creates great incentives for American businesses to accommodate Latina/o and Asian minorities. Instead, however, these immigrants meet great disadvantages and unfair

3. The U.S. Census reports that in 2000 , there were approximately 10.2 million Asians in the United States, accounting for $3.6 \%$ of the total population, and 35.3 million Hispanics and Latinas/os in the United States, accounting for $12.5 \%$ of the total population. See U.S. Census Bureau, Census 2000 PHC-T-i, Population by Race and Hispanic or latino Origin for the United STATES: 1990 AND 2000 (Apr. 2, 2001), available at http://www.census.gov/population/cen 2000/phetl/tab01.pdf.

4. See infra text accompanying notes $77-91$ and note 84 (identifying Spanish- and Asianlanguage-speaking immigrants as "racial-language minorities" who are uniquely targeted by discriminatory English-only policies, unlike non-English-speaking white immigrants).

5. See Steven W. Bender, Consumer Protection for Latinos: Overcoming Language Fraud and English-Only in the Marketplace, 45 AM. U. L. REv. 1027, 1034-35 (1996). Language minorities can be subject to further exploitation by those who speak their languages or share the same ethnic background, leading to what regulators call "affinity fraud." Susan Sachs, Welcome to America, and to Stock Fraud, N.Y. TIMEs, May 15, 2001, at Al (identifying immigrants as a particularly vulnerable population, who because of barriers and lack of access to information in an English-dominated society are easily enticed to trust deceitful brokers who speak their languages but who abuse that trust). The article notes that "[w]hen it comes to separating immigrants from their money, few techniques have gone untested." Id. See also David Montero, Attorney General Files Civil Suit Against Water Scam Trio, Ventura COUNTY STAR, Aug. 22, 2001, at B01 (lawsuit brought against sellers who fraudulently sold highpriced water-filtration systems to primarily non-English-speaking Latina/o residents in southern California, using Spanish contracts containing no disclosures about interest rates and which were later filled out in English); Adolfo Pesquera, Air Conditioning Rip-Off Alleged, San Antonio ExpressNEws, Oct. 5, 2001, at IE (deceptive trade practices lawsuit brought against Hispanic Air Conditioning $\&$ Heating lnc. on behalf of Spanish-speaking customers after improper installation of air-conditioning units and damage to homes). 
practices when encountering business merchants and the morals of the marketplace. ${ }^{6}$ Consumer-protection legislation counteracts some of those disadvantages and seeks to safeguard language minorities. However, such regulation still "too often assumes that consumers are proficient in English or, if not, are accompanied in their transactions by an interpreter... [leaving] Latinos/as and other language minorities the victims of choice for unscrupulous merchants who prey on their inability to understand the terms of the bargain."

Recognition of the rights of language minorities in the economic marketplace is thus all the more imperative to leveling a persistently uneven playing field in this ostensible "land of opportunities." The need to protect non-English speakers against economic exploitation and to have their economic rights affirmed creates a difficult but timely project for supporters of social justice. However, identifying the source of protection and establishing a basis upon which we may begin the endeavor of upholding the economic rights of language minorities in the marketplace presents a significant and immediate challenge. Since no area of law is more driven by economic ideals than contract law, it initially seems a fitting place from which we may begin to unravel the impaet of language disparities in the marketplace. Yet contract law has not been often applied to the work of remedying the undesirable consequences of language-based exploitation.

This Comment challenges the differential treatment of immigrant minorities based on language, particularly as it relates to the often-ignored economic rights of minorities. In so doing, it specifically questions how economic and business-driven visions of contract law have affected the economic rights of non-English-speaking minorities through the explicit recognition - or not so explicit underrecognition —of their language rights. Although some work has addressed the particular language-based hurdles and discrimination experienced by immigrant consumers and employees in the marketplace, virtually no scholarship exists attending to the needs of another substantial and growing subset of immigrant market actors in U.S. society: small-business owners.

In approaching the difficulties encountered by language minorities in the marketplace, Part I proposes that immigrants who own small businesses are ideal economic actors through whom we may attempt to sufficiently account for marketplace inequities by means of contract law. Despite the challenges of transacting through language barriers, these small-business owners regularly contract with English-speaking vendors and suppliers, primarily through the medium of English-language standardized forms. Typically, when dissatisfied with the vendor's performance, a business owner contemplates protecting her business interests by pursuing a

6. See Bender, supra note 5, at 1032.

7. Id. at 1029-30. 
contract-based claim. Curiously, fcw instances of disputes involving immigrant small-business owners exist within contract case law. The economic and business needs of immigrant small-business owners thus pose a peculiar predicament in contract law. Although disputes between non-Englishspeaking business owners and English-speaking vendors inevitably occur on a widespread basis, little case law exists reporting disputes between economic actors at this level who transact through language barriers and whose bargaining process may have been substantially influenced by the differences in language abilities.

In Part II, this Comment explains this discrepancy between market rcalities and case law by examining contract law's avoidance of social considerations and fairness issues. Founded upon a premise of contractual frecdom, traditional contract law envisions a transactional world in which rational and informed market actors enter into an efficient and objective system of bargains and deals. In such a world, fairness notions and issues relating to social status factors, such as race, remain superfluous and irrelevant. At the same time, though, language remains an integral component of contract law, for it is through language that parties bargain and transact with each other. It is through language that parties are informed of the legal rights and obligations owed to each other. The avoidance of languagebarrier issues within contract-law jurisprudence, and the correlating underrecognition of language-based contractual disputes as established in Part I, thus present yet another unique conundrum. ${ }^{8}$

This paradox can be reconciled, however, by examining the ways in which language coincides with racial identity in U.S. society. ${ }^{9}$ The latter half of Part II explores how language often serves as a proxy for race in the United States and argues that contract law's avoidance of and detachment from minority-language-based issues betrays the subtle understanding of thc ways that language constitutes race. Where language cquals race, the lack of case law, or any jurisprudential discussion at all, regarding the transactions by language minorities reflects the classical vision of contract law as detached from socially relevant factors. More importantly, in light of the ways in which language matches up with racial identity, the denial or suppression of the social, political, and economic benefits of this country to an immigrant because she speaks a language other than English amounts to an insidious manifestation of group discrimination and prejudice. By disengaging from socially determinative factors such as race, contract law as

8. Admittedly, perhaps immigrant business proprietors have been able to address their contractual needs without explicitly addressing language-barrier factors. However, when accounting for the integral role language plays in contract law, and thus the potential within contract law to address language-based commercial disputes head-on, the resort away from explicitly addressing language barriers seems unnecessarily forced and reifies the perception of contract law as detached from socially relevant factors.

9. See infra text accompanying notes 77-91. 
practiccd poses a threat in itself to racial-language minorities and furthers their disempowerment. Contract law's failure to address language-based issucs adequately does not remove these language and thus race-based factors. Rather, this failure reifies the English-language norm and thereby furthers the maldistribution of rights based on language and racial identities.

At the same time, contract law retains significant potential to ameliorate the language-based challenges encountered by language minorities. To be sure, modern contract law has made progress in accommodating social considerations and fairness issues, and Part III examines these legal developments. With the advent of doctrines such as fraud and unconscionability, contract law opened a door through which the challenging issues encountered by non-English-speaking minorities might be asserted and redressed. Yet despite the contractual protections of language minorities suggested by the fraud and unconscionability doctrines, these doctrines do not sufficiently remedy marketplace inequities. On thc one hand, there will not always be evidence of fraud in transactions involving language barriers. On the other hand, although applicable to employee or consumer subgroups within minority communities, the doctrine of unconscionability resists application to minorities who appear to stand on more equal footing with the other bargaining party, such as small-business owners who contract for services with English-speaking vendors and suppliers. These minorities, however, still experience many challenges to their economic participation based on their language abilities. This Comment proposes that the failure of the fraud and unconscionability doctrines fully to address the challenges encountered by language minorities in general coincides with the failure to protect the economic rights of immigrant small-business owners.

Part III continues by returning directly to the context of immigrant small-business owners and to the form-contract setting in which they generally intcract with English-speaking vendors. ${ }^{10}$ To better address the barriers to the economic rights of language minorities, we need a comprehensive vision of law that extcnds those rights not only to thosc who appear most vulnerable to language-based economic exploitation, but also to all who face such deprivation of rights, including our entrepreneurs and business venturers. For these economic actors, to whom an unconscionability analysis may not apply, the asscnt-based rules governing form contracts and interpretation provide an alternative source of protection. Unlike unconscionability and fraud, which were developed to operate under the auspices of social-fairness directives but which often avoid mattcrs of language and race if possible, assent-based mcthods implicitly accept the relevance of language in the bargaining process. They are designed for interpreting the language of the contract, whether it comes in the form of

10. Form contracts are preprinted forms containing standardized terms which are often and routinely utilized in commercial transactions. See infra text accompanying notes 120-25. 
express verbal communication or conduct. The explicit recognition of language issues is thus often central to the assent-based methods and provides a formidable basis upon which minorities may remedy their business disputes with English-speaking vendors. ${ }^{1}$ Furthermore, by addressing the issue of language barriers directly, assent-based methods may provide an affirmative foundation upon which to assert the rights of immigrant minorities to receive contracts in their own languages.

Importantly, assent-based approaches to language-based contract issues do not radically alter the current state of contract law. Part IV asserts that in the process of protecting the economic and language rights of raciallanguage minorities, language recognition through contract law remains consistent with the evolving principles of modern contract law and formcontract rules. Only this time the rules work more equitably. Contract law no longer remains a protective device only for English-speaking bargainers; it becomes equally accessible to racial-language minorities. The assent-based approaches thus afford the non-English-speaking minority actor with a potent and effective means by which she may pursue her economic and business claims.

At the same time, the application of assent-based methods to disputes arising out of language barriers furthers contract law's progress toward more accurately reflecting bargaining behavior by actual persons. By accounting for language and racial factors through assent-based methods, contract law bridges the gap between its sterile self-perception and the events that transpire at the real bargaining table. The assent-based approaches may thus facilitate contract law's understanding of its direct effect on suppressing or empowering the economic rights of racial-language minorities. With this understanding may come more equitable and workable rules that do not lend their application to the suppression of those rights.

I include some caveats: This Comment will focus exclusively on a contract-law analysis of language barriers and will not discuss any legislative approaches to ameliorating language burdens of non-English

11. By all means, the assent-based methods proposed later in Part III may apply generally to all non-English speakers, including White immigrants. However, this Comment focuses primarily on racial-language minorities (Spanish- and Asian-language speakers) to investigate the implications of English-only norms, as reified in contract law, on race relations. Many scholars have recognized English-only positions as xenophobic stances against non-White immigrants from Asia and Latin Ameriea. See infra text accompanying notes 78-80. Historians have further tracked the development of a "White" identity more inclusive than its Anglo-Saxon predecessor, and the assimilation into "Whiteness" of groups previously considered separate races, such as the Irish, Jews, and Italians. See Evelyn Nakano Glenn, Unequal Freedom: How Race and Gender Shaped american CITIZENSHIP AND LABOR 10 (2002). Thus insofar as White immigrants from non-English-speaking countries can experience the privileges that accompany "Whiteness," the language barriers encountered by them do not function to maintain racial subordination. 
speakers. ${ }^{12}$ By the same token, while recognizing the significant scholarship concerning constitutional recognition of language rights, this Comment will not apply an equal protection analysis to the contract disputes brought by immigrant small-business owners. ${ }^{13}$ For one thing, the application of equal protection to language rights by courts is often limited. ${ }^{14}$ It usually depends on a well known but problematic mutable-traitversus-immutable-trait analysis. ${ }^{15}$ Moreover, although constitutional rights have shaped certain areas of the law (for examplc, employment, government services, education, immigration, franchisement, and criminal procedure), where "language or ethnic-group interests are less easily organized for assertion, as in private disputes involving construction of contracts ... the constitutional dimensions are less prominent." 16

A more central reason for exclusively focusing on a contract-law analysis, however, is that a predominant part of the agenda of this Comment is to dispute the persistent notion that contract law is separate from social and fairness issues, and is independent of social factors such as race.

12. For a discussion on legislative approaches, see generally Bender, supra note 5.

13. Most cases involving discrimination by language elassification have been remedied as suspect or semisuspect classifieations to meet the 14th Amendment's Equal Protection Clause framework. See Note, "Official English": Federal Limits on Efforts to Curtail Bilingual Services in the States, 100 Harv. L. Rev. 1345, 1353 (1987); see also Hernandez v. New York, 500 U.S. 352 (1991); Lau v. Nichols, 414 U.S. 563 (1974); Hernandez v. Texas, 347 U.S. 475 (1954); Yu Cong Eng v. Trinidad, 271 U.S. 500 (1926); Meyer v. Nebraska, 262 U.S. 390 (1923); Garcia v. Spun Steak, 998 F.2d 1480 (9th Cir. 1993); Fragrante v. City and Council of Honolulu, 888 F.2d 591 (9th Cir. 1989); Gutierrez v. Mun. Court, 838 F.2d 1031 (9th Cir. 1988), vacated as moot, 490 U.S. 1016 (1989); NAACP v. City of Richmond, 743 F.2d 1346 (9th Cir. 1984); Asian Amer. Bus. Group v. City of Pomona, 716 F. Supp. 1328 (C.D. Cal. 1989). See generally Perea, supra note 2; Michele Arington, Note, English-Only Laws and Direct Legislation: The Battle in the States over Language Minority Rights, 7 J.L. \& PoL. 325 (1991); Andrew P. Averbach, Note: Language Classifications and the Equal Protection Clause: When Is Language a Pretext for Race or Ethnicity?, 74 B.U. L. REv. 481 (1994); Susan Kiyomi Serrano, Rethinking Race for Strict Scrutiny Purposes: Yniguez and the Racialization of English Only, 19 Haw. L. Rev. 221 (1997).

14. See Arington, supra note 13, at 335. Arrington wrote:

Equal protection challenges to English-only policies have frequently been rejected because courts do not consider non-English speakers, taken as a whole, to be a suspect class and therefore do not subjeet such policies to heightened scrutiny. Nor have eourts identified language as a fundamental right which triggers strict scrutiny analysis.

Id.

15. For criticisms of the mutable-trait-versus-immutable-trait analysis, see Matsuda, supra note 1, at 1400; see also Leslie Espinoza \& Angela Harris, Afterword: Embracing the Tar-Baby-LatCrit Theory and the Sticky Mess of Race, 10 LA RAzA L.J. 499, 537 (1998), 85 CALIF. L. Rev. 1585, 1623 (1997). Espinoza and Harris wrote:

If race is an immutable trait-for example, if it is reduced to skin color-then anything that looks 'mutable' must not be protected by laws against race discrimination. In this way, discrimination against Latinas/os on the basis of the language they speak is legally maintained-and even fostered. For the opposite of an immutable trait in the law turns out to be a free choice, and it is perfectly legitimate for employers and others to encourage people to choose one thing over another: to 'choose' to speak English rather than Spanish, for example.

Id.

16. Peter W. Schroth, Language and Law, 46 AM. J. ComP. L. 17, 33-34 (Supp. 1998). 
In analyzing the consequences of contract law's imposition of an unofficial but powerful English-only rule and examining the corresponding racial implications, this Comment seeks to elucidate the extent to which race and other social factors are directly implicated in contract doctrines and principles. It thus seeks to emphasize the potential in contract law for ultimately upholding the rights of racial-language minorities, as well as the rights of other economically oppressed groups in our society.

\section{Racial-Language Minorities as Economic Actors}

The economic rights of language minorities cover a full range of daily marketplace activities, as a minority individual ventures in turn through the U.S. economy alternately as an employee, employer, consumer, supplier, and so on. Within the legal discipline, however, there continues to be very little identification of the language minority as a relatively advanced, business-savvy economic actor. The needs of such language minorities who have stepped into entrepreneurship remain underdeveloped, despite evidence of a significant growth of minority-owned businesses in the country. Census reports reveal a continuous increase in Latina/o- and Asian-owned businesses, significantly contributing to the structure and functioning of the U.S. economy. The 1997 economic census ${ }^{17}$ compiled by the U.S. Census Bureau reported that Latinas/os and Asians owned approximately 2.1 million of all nonfarm businesses in the United States, approximately $10.2 \%$ of the 20.8 million nonfarm businesses in the country. ${ }^{18}$ These Latina/oand Asian-owned businesses are primarily operated in the service and retail industries $^{19}$ as individual proprietorships. Seventy-one percent of Asianowned businesses and over $85 \%$ of Hispanic-owned businesses operated as

17. The 1997 economic census is the most rccent economic census available to date. Title 13 of the United States Code (sections 131, 191, and 224) directs the Census Bureau to take the economic census every fivc years, covering years ending in -2 and -7 . See U.S. Census BurEaU, 1997 ECONOMIC Census, Survey of Minority-Owned Business Enterprises: Asians and Pacific lslanders 1 (May 2001) [hereinafter 1997 ECONOMIC CENSUS: Asians], available at http:/www.census.gov/ prod/ec97/e97cs-5.pdf.

18. See id. at 9 (reporting that Asians and Pacific lslanders owned 912,960 of all nonfarm businesses in the United States, accounting for $4.4 \%$ of the nonfarm businesses in the country); U.S. Census Bureau, 1997 EConomic Census, Survey of Minority-Owned Business ENTERPRISES: HisPanics 9 (May 2001) [hereinafter 1997 ECONOMIC CENSUS: HisPanics], available at http://www.census.gov/prod/ec97cs-4.pdf (reporting that Hispanics owned 1.2 million of all nonfarm businesses, approximately $5.8 \%$ of all nonfarm businesses in the United States).

19. Forty-four percent of all Asian-owned businesses and $42 \%$ of all Hispanic-owned businesses operated in the service industries (primarily in the business and personal services), and $21.4 \%$ of all Asian-owned businesses and 12.9\% of Hispanic-owned businesses operated in retail. See 1997 Economic Census: Asians, supra note 18, at 9; 1997 Economic Census: Hispanics, supra note 18, at 9. The primary operations within the retail industry are "automotive dealers and service stations," "eating and drinking places," and "food stores." See 1997 Economic Census: AsIans, supra note 18, at 9, tbl. A; 1997 Economic Census: Hispanics, supra note 18, at 9, tbl. A. 
individual proprietorships in $1997 .{ }^{20}$ In light of the significant growth trend exhibited in these immigrant populations, ${ }^{21}$ the implication for the American economy could be even greater market contribution by Latina/oand Asian-owned small businesses in the future. In states like California, with Latina/o and Asian immigrant communities on the rise, there has already been a significant increase in business ownership by members of these communities. ${ }^{22}$

Problematically, however, while Latina/o and Asian Americans are finding increasing opportunities in owning small businesses, the average receipts per business for Latina/o- and Asian-owned businesses are consistently subaverage in every industry division. ${ }^{23}$ For example, while the average receipts for an American business in the service industry were reported at $\$ 294,000$, Asian-owned busincsses reported an average of $\$ 167,000$ and Hispanic-owned businesses reported $\$ 78,000$ during the same time period. ${ }^{24}$ The average receipts for an American business in the retail trade industry were $\$ 917,000$, while Asian-owned businesscs reported $\$ 347,000$

20. See I997 EConomic Census: Asians, supra note 18 , at $10 ; 1997$ EConomic Census: Hispanics, supra note 18, at 10. The U.S. Census Bureau defines individual proprietorships as "unincorporated business[es] owned by an individual. Also included in this category are selfemployed persons." I 997 ECONOMIC CENsus: Asians, supra note 18, at A-1. Proprietorships are thus distinguished from other legal forms of organizations, such as corporations and partnerships, and constitute the small businesses in which significant numbers of Asians and Latinas/os invest their time and money.

21. In the past decade, there was a $48.3 \%$ increase in the Asian population and $57.9 \%$ in the Latina/o population. See U.S. Census Bureau, Census 2000 PHC-T-I, Population by Race and HispaniC OR Latino Origin fOR the UNITED STATES: 1990 and 2000 (Apr. 2, 2001), available at http://www.census.gov/population/cen2000/phc-tl/tab04.pdf. See generally U.S. Census BurEau, Census 2000 Brief, The Asian Population: 2000, at 1 (Feb. 2002), available at http://www.census.gov/prod/2002pubs/c2kbr01-16.pdf. Because of the changes between the 1990 census and the 2000 census, the data on race are not directly comparable. See id. at 2 . At the least, however, the data demonstrates the continuous growth of the Asian and Latina/o populations in the United States. Significantly, these figures represcnt not only American-born individuals, but also include a sizable population of foreign-born individuals who bring with them a formidable language barrier. See U.S. Census Bureau, Census Brief, Coming from the Americas: A Profile of the Nation's Latin American Foreign Born 1 (Sept. 2000), available at http://www.census.gov/ prod/2000pubs/cenbr003.pdf (reporting that in 1997, 13.1 million, or about half, of the nation's foreignborn residents were born in Latin America, with Mexican-born individuals accounting for $28 \%$ of the foreign-born population and more than half of the population from Latin America); U.S. CENsus Bureau, Census Brief, From the Mideast to the Pacific: A Profile of the Nation's Asian FOREIGN BORN POPULATION 1 (Sept. 2000), available at http://www.census.gov/prod/2000pubs/ cenbr004.pdf (reporting that 6.8 million of the nation's foreign-born were born in Asia, comprising $27 \%$ of the foreign-born population in the United States).

22. See 1997 ECONOMIC Census: AsIans, supra note 18, at 9 (finding that $34.6 \%$ of all Asianowned businesses operated in California); 997 ECONOMIC CEnsus: Hispanics, supra note 18, at 9 (finding that $28 \%$ of all Hispanic-owned businesses operated in California).

23. See 1997 EConomic Census: Asians, supra note 18, at 15, fig. 4; 1997 EConomic Census: Hispanics, supra note 18, at 15, fig. 4; see also Kevin Davis, Grabbing a Fair Share; Minorities Make Progress but Obstacles Remain, Crain's Chicago Business, Oct. 22, 2001, at ME1.

24. See I997 Economic Census: Asians, supra note 18, at 15, fig. 4; 1997 Economic Census: Hispanics, supra note 18, at 15, fig. 4. 
and Hispanic-owned businesses reported $\$ 208,000 .^{25}$ With $71 \%$ of Asianowned businesses and over $85 \%$ of Hispanic-owned businesses operating as individual proprietorships, ${ }^{26}$ it is certain that many of the businesses reflecting this disproportionate marketplace performance are individualowned small businesses.

These figures reveal a potentially disturbing picture about the performances of Asian- and Latina/o-owned small businesses in the marketplace. Of course, the disparity in market power between immigrant-owned small businesses and the "average" American business may be attributable to the immigrant small-business owner's market niche. The Asian- or Latina/o-owned business may target a specifically Asian or Latina/o consumer base, which does not extend to the "average" American consumer in the neighborhood. Geographic factors might influence the disparity in business performances. At the same time, deficient sampling methodology may inaccurately reflect the market presence of immigrant businesses. ${ }^{27}$

Despite such factors, however, the disparity in language efficiency in the marketplace should not be underestimated. The language skills of the business owner are not only essential for greater marketing and advertising strategies to garner more customer business, but are also a vital asset when requesting and contracting for services from vendors and suppliers. More often than not, business owners enter into regular contracts with their vendors and suppliers based on standardized or form contracts, usually provided by the vendor or supplier. Inevitably, "even between persons of good intentions, disputes are likely to arise concerning such matters as quality, conformity to sample, privileges of return, [or] packing and shipping instructions." ${ }^{28}$ ln other words, it should not be uncommon or exceptional for an immigrant small-business owner to become dissatisfied with the level of performance on the part of her English-speaking vendor or supplier, who may have provided less-than-satisfactory services or a defective shipment of requested products. The recourses available to the business owner in the face of shoddy or incomplete performance become the focus of our contract-centered attention.

In general, when such commercial disputes arise, the parties would probably point first to the form contract and resolve their differences, even if it means pursuing their elaim through a settlement or a trial verdict.

25. See 1997 Economic Census: Astans, supra note 18, at 15, fig. 4; 1997 EConomic Census: Hispanics, supra note 18, at 15, fig. 4.

26. See supra note 20.

27. For example, Professor Bender notes that "those unable to speak English are often uncounted." Bender, supra note 5, at 1033. Some have further observed that lack of bilingual census takers and fear of rcpercussions from the 1 mmigration and Naturalization Service may primarily contribute to the underreporting by racial-language minorities. See id. at $1033 \mathrm{n.13}$ (citing Frank M. Lowrey, IV, Comment, Through the Looking Glass: Linguistic Separatism and National Unity, 41 EMORY L.J. 223, 266 n.229 (1992)).

28. Lon L. Fuller \& Melvin Aron Eisenberg, Basic Contract Law 621 (6th ed. 1996). 
However, a unique divergence arises at this point between Englishspeaking parties and language minorities in the contract-based protection of their economic interests. A whole subsection of contract law has developed around the legal issues of form contracts created between two English-speaking parties who thereafter dispute the validity and invalidity of certain standardized documents. ${ }^{29}$ However, little reported case law involves conflicts between English speakers and language minorities at this economic level, or at least none involve a language barrier brought to the forefront as an issue directly related to the contract.

The lack of language-based disputes involving parties at this economic level is surprising, given that disputes regarding vendor performance are inevitable. Disputes must exist, then, and in light of the vital role that language plays in contract formation and interpretation by the parties, there must exist at least some disputes in which language-barrier issues were highly influential if not determinative. The language used by a party communicates to the other the obligations owed, constructing the terms of the contract to a significant degree. In essence, the language creates the contract. It is thus perplexing that more cases do not exist in which parties argue the invalidity of a contract or term by relying on language-based factors. Assuming that the lack of reported language-based disputes between immigrant small-business owners and their English-speaking vendors cannot conceivably mirror the actual market, we face a legal "silence" demanding our inquiry and skepticism, the source of which can only be unearthed by a deeper examination of the relationship between contracts and language.

\section{II}

Contract Law's Perpetuation of the English-Language Norm and ITS HARM

The disparity between experience and reported case law can be explained by examining the definitive features of: (1) contract law, which traditionally eschews social considerations and fairness issues, such as those relating to race, and (2) language, which acts as a proxy for race when minority immigrants are involved. The following discussion asserts that the underacknowledgment of language-based disputes reflects contract law's discouragement of immigrant business owners from bringing language-based actions in the first place. Combining a politics of contract law, which shies away from notions of race, with pro-English policies that are firmly, even if unofficially, established throughout U.S. institutions, the

29. See id. at 614-68 (giving great attention to contract formation and interpretation cases in a form-contract setting). Although the cases do not specify that all parties to a contract spoke English, language issues are not present, and we can presume that the parties did not transact through language barriers. 
market dissuades language minorities from pursuing potentially viable economic claims against the vendor or supplier. She thus relinquishes her economic rights and must shoulder the burden of the vendor's questionable performance herself. To better understand this outcome, however, we must first consider the basic premises of eontract law which cause eontract-law doctrines disproportionately to impact language minorities.

\section{A. The Tenuous Social-Fairness Notion in Contract Law}

Much of modern contract law continues to be driven by the classical contract premise of freedom of contract. ${ }^{30}$ Under this theory, a contract need only fit the form (that is, be supported by some consideration); it need not demonstrate an equality or fairness in the exchange. ${ }^{31}$ As many courts in the past have articulated, "Mere inadequacy of consideration will not void a contract." ${ }^{\prime 2}$ Thus, once the parties transact pursuant to clear, formalized rules (that is, when they exchange consideration and assent by a "meeting of the minds"), the parties are bound to each other by contract. The entire content of the parties' agreement, and the entire source of their obligation to one another, becomes locked into that initial "magic moment of agreement."${ }^{933}$

The normative rationale espoused in this classical view is the ideal of liberal individualism, the assumption being that rational parties, exercising their free will and driven by their own prcferences, are in the best positions to fashion bargains appropriate for their needs. ${ }^{34}$ This theory presumes an efficient system of rational and well-informed wealth maximizers, and contract law's primary objective becomes merely the enforcement of the parties' promises and the protection of their bargaining will. ${ }^{35}$

Presuming encounters between rational and well-equipped actors, standard discussions of contract law promote a model of objective "empiricism, highlighted by clearly defined rules that serve practical goals

30. See Larry A. DiMatteo, Equity's Modification of Contract: An Analysis of the Twentieth Century's Equitable Reformation of Contract Law, 33 NEw ENG. L. REv. 265, 267 (1999).

31. See id. at 290 .

32. Batsakis v. Demotsis, 226 S.W.2d 673, 675 (Tex. 1949) (where plaintiff loaned defendant, who was stuck without funds in Greece during World War II, the equivalent of $\$ 25$ in exchange for defendant's promise to repay plaintiff $\$ 2,000$ upon defendant's return to the United States).

33. Paul J. Gudel, Relational Contract Theory and the Concept of Exchange, 46 Buffalo L. REv. 763, 767-68 (1998).

34. See id. at n.31 (citing Charles Fried, Contract as Promise 1-6 (1981) ("The will theory of contract, which sees contractual obligations as essentially self-imposed, is a fair implication of liberal individualism.") and P.S. ATIYAh, Promises, MORALS, AND LAW 1-8 (1981) ("The classical model of contract grew up under the shadow of a number of intellectual movements which stressed the importance of free choice and consent as the origin of legal and moral obligation alike.")); see also Blake D. Morant, The Relevance of Race and Disparity in Discussions of Contract Law, 31 NEw ENG. L. REv. 889, 901 (1997).

35. DiMatteo, supra note 30, at 267 n.649 (citing A.H. Manchester, A Modern Legal HISTORY OF ENGLAND AṆD WALES I 750-1950, at 571, 575 (1980)). 
focused upon market preservation." 36 Designed around seemingly impartial ends, such as guiding parties in the formation of prospective bargains, encouraging the creation of bargains by minimizing transaction costs, and allocating resources, these contract rules resist incorporating subjective factors that often complicate the bargaining process. ${ }^{37}$ As Blake Morant rightly observes:

On its face, the theory of contract is objective, eschewing any notion of societal inequities. ... The theoretical basis for contract, and bargaining conduct in general, revolves around the notion of assent and the need for some bargained for exchange of value. ${ }^{38}$

Queries into the parties' relative bargaining positions and questions as to the fairness of the bargain are kept off the bargaining table, as it were, and the classical ideology of contract law tends instead towards a reliance on seemingly objective market forces to even out human relations. ${ }^{39}$

The modern complexities of an advanced and industrialized society, however, have challenged this objective construct of classical contract law. Despite its appealing "aura of certainty, stability, and predictability," ${ }^{400}$ fostered by an emphasis on formalized rules, in actuality the classical paradigm cracked due to the real human factors involved in its application. ${ }^{41}$ Because subjective factors inevitably entered the realm of contract law, courts regularly "had to interpret, fill gaps, and even impose

36. Morant, supra note 34 , at 890.

37. Id.

38. Blake D. Morant, The Teachings of Dr. Martin Luther King, Jr. and Contract Theory: An Intriguing Comparison, 50 ALA. L. REv. 63,68 (1998).

39. See id. at 69.

40. DiMatteo, supra note 30 , at 268.

41. Id. This has led many recent contract-law scholars to ardently propose limiting the classical contract view of autonomous, objective contracting in favor of espousing theories which account for real, human, societal conditions. For example, Ian Macneil's relational contract theory rejects the presumption of humans as rational, self-serving, and opportunistic wealth maximizers, envisioning instead a richer and more complicated human relationship. Solidarity and reciprocity become the driving forces of transactional behavior and reflect more appropriately the dynamics of transactional behavior than notions of efficiency and individual wealth maximization. Ian R. Macneil, Values in Contract: Internal and External, 78 Nw. U. L. Rev. 340, 348-349 (1983). Contract law is then a law of relationships where most, if not all, modern contracts are "characterized by long duration, personal involvement by the parties and the exchange, at least in part, of things difficult to monetize or otherwise measure." Gudel, supra note 33, at 765. For more on relational contract theory, see generally Ian R. Macneil, The Relational Theory of Contract: Selected Works of Ian Macneil (David Campbell ed. 2001); 1an R. Macneil, The New Social Contract (1980). For an overview of Macneil's theory, see generally Gudel, supra note 33. For a critical take on relational contract theory, see Melvin A. Eisenberg, Why There Is No Law of Relational Contracts, 94 Nw. U. L. Rev. 805 (2000).

Melvin Eisenberg likewise offers a "dynamic" theory of contract law, in which the rules of contract reflect modern social realities characterized as "individualized rather than standardized, subjective rather than objective, complex rather than binary, and dynamic rather than static." Melvin A. Eisenberg, The Emergence of Dynamic Contract Law, 88 CALIF. L. Rev. 1743, 1745 (2000). Professor Eisenberg reeommends a theory by which contract doctrines properly take into account the society's moral, policy, and empirical propositions. Id. 
pre-contractual and quasi-contractual liability" to make the parties' contract meaningful in its commercial context. ${ }^{42}$ Additionally, instead of adequately reflecting the parties' promises and volition, classical contract principles in practice increasingly enabled and justified transactions that were widely recognized as unfair and problematic. ${ }^{43}$ In contrast to classical contract law's ideal discrete, one-shot transactions, the modern commercial world saw a rise in long-term "relational contracting," characterized by "asymmetrical information" between the parties and consequently an incomplete or misinformed distribution of risk. ${ }^{44}$ Classical contract law's presumption of rational parties coming to the bargaining table equipped and protected with complete information became an illusion, requiring new rules that would engage questions of unfairness in bargaining practices.

With the development of more equitable doctrines such as reliance, duress, and unconscionability, modern (sometimes called "neoclassical") contract law thus provided modern parties with a compromise:

The core [of neoclassical contract law] remains the principle of freedom of contract ... but this principle is "tempered both within and without [contract's] formal structure by principles... that focus on fairness and the interdependence of parties rather than on parties' actual agreements." In deciding the scope of contractual liability, courts weigh the classical values of liberty, privacy, and efficiency against the values of trust, fairness, and cooperation. ... ${ }^{45}$

By formally recognizing "the values of trust, fairness, and cooperation" through doctrines such as unconscionability, modern contract law finally began to account for social factors that no doubt influenced and determined the parties' capacities to have a "meeting of the minds" and give unequivo$\mathrm{cal}$, informed assent to the contract. Consideration plus assent no longer remained the end all and be all of a contract.

It is still critical to recognize that despite the steps madc by modern contract law to react adequately to social experiences, what is considered an adequate redress can still be significantly compromised. The current politics of contract law "attempt[] to balance the individualist ideals of classical contract with communal standards of responsibility to others." ${ }^{\$ 46}$ The ever-present standards of classical contract law underlie this modern balance: a contract is presumptively individualist and should be objectively analyzed unless sufficient proof of deviation from communal standards has been provided.

42. Jay M. Feinman, The Significance of Contract Theory, 58 U. CIN. L. REv. 1283, 1287 (1990).

43. See DiMatteo, supra note 30, at 321.

44. Id. at 315 .

45. Feinman, supra note 42, at 1288 (quoting Hillman, The Crisis in Modern Contract Theory, 67 TEX. L. Rev. 103, 104 (1988)).

46. Id. at 1287-88. 
On the whole, then, although contract law provides a forum for the consideration of social values other than individualism, it retains the "freedom of contract" ethos as its core. As a result, modern contract law persists in limiting its engagement with social-fairness issues, often turning a blind eye to socially relevant elements that inevitably influence contracting behavior ${ }^{47}$ Even doctrines specifically tailored to account for unfairness issues, such as unconscionability, remain evasive when it comes to socially rich factors such as race, leading Blake D. Morant to note that "[c]onspicuously absent from cited considerations within the unconscionability doctrine is the concept of race." ${ }^{.48}$ A classic example of this oversight is found in Williams v. Walker-Thomas Furniture Co. ${ }^{49}$ which could have incorporated at least some discussion of race and gender into its analysis. But nowhere in this well-known opinion does the court ever explicitly acknowledge that the plaintiff is an African-American woman on government assistance, thus never acknowledging the contextual realities which may have affected the contractual behavior of the parties, such as stereotypes based on race. ${ }^{50}$

The consequences of such an oversight should not be lightly dismissed. As an initial matter, the omission creates an inaccurate account of what transpires at the metaphorical bargaining table, potentially undermining the intended effect of any legal remedy aiming to uphold the economic rights of the relatively "weaker" bargaining party. ${ }^{51}$ At a deeper level, the oversight reinforces the detachment or disengagement between contract law and race, removing from the contractual picture a highly sensitive, complicated social matter. But the removal of race from contract discussion does not innocuously simplify the issues. Rather, it implies that race

47. In addition to race, many scholars have criticized contract law's treatment of gender. See, e.g., Deborah L. Threedy, Feminists \& Contract Doctrine, 32 IND. L. Rev. 1247 (I999); Patricia A. Tidwell \& Peter Linzer, The Flesh-Colored Band Aid-Contracts, Feminism, Dialogue, and Norms, 28 Hous. L. Rev. 79I (I991). Threedy wrote:

Contract law, like law generally, is said to be male-gendered because of the perceived presence of these traits. In other words, contract law is not neutral; it is one of the many social structures that supports a male preference. Further, it is not objective; it has perspective, but its point of view is masked.

Threedy, supra, at I249.

48. Morant, supra note 34 , at 924.

49. 350 F.2d 445 (D.C. Cir. I965).

50. Morant, supra note 34, at 926-29.

5I. Contrast with Weaver v. Am. Oil Co., 257 Ind. 458 (1971), in which the court focused much attention on the fact that the plaintiff was a man of poor education who spent most of his time working in skilled- and unskilled-labor jobs, leaving him open to abuse by the more legally and economically sophisticated defendant oil company. After denouncing the oil company's adhesive contract as "contrary to public policy," the court went beyond striking the contract as unconscionable and strengthened the rights of the plaintiff by articulating a rule that ultimately placed the burden on the party seeking to enforce a disputed term to show that "the provisions were explained to the other party and came to his knowledge and [that] there was in fact a real and voluntary meeting of the minds and not merely an objective meeting." Id. at 464-65. 
has no relevance to discussions of fairness or burden within the bargaining transaction at all. ${ }^{52}$ It effectively extinguishes the relevance of race, with the associated influences of racial perceptions and racist intents, from contract-law discourse. At the same time, by misrepresenting the actual interactions between race and law in market transactions, and by ignoring the real social pressures that may unfairly manipulate the bargaining process, contract law's avoidance of discussions of race ultimately risks occluding the potential in contract law affirmatively to uphold the economic rights of racial minorities. The danger is not just that contract law will inaccurately reflect bargaining behavior and result in misguided rules and applications. The danger is also that those whose economic rights are most challenged will not be able to access the laws and rules that purport to uphold everyone's economic rights. This scenario appears especially likely in the case of immigrant small-business owners and their underacknowledged language-based claims. Thus we are brought back to the task at hand and to the investigation of contract law's applicability to the business claims of non-English-speaking immigrant proprietors.

Ascertaining contract law's tendency to disengage from race discourse, however, establishes only part of the reason why there appears to be no record of immigrant business owners raising language-based claims. A fuller understanding of contract law's disconnection from a non-English speaker's language-based claims requires a further analysis of the role of language in U.S. society as a socially "thick" identity marker. By surveying the ways in which non-English languages such as Spanish and Asian languages have become targets for prejudicial and discriminatory thinking, Part II.B explores the ways in which language has become a proxy for race in the United States. Having already established contract law's avoidance of race discussion, defining language in terms of race completes the contextual analysis and provides a perspective from which we can explain the lack of language-based claims in contract law.

\section{B. Language and Racial Identity in U. S. Society}

On an individual level, there are ways of thinking and being so contained in language that a person could not be who she is without the particular language..$^{53}$ It remains central to our individual identity and "in our very humanity." ${ }^{54}$ At the same time, however, language contains a political and often national dimension, and it becomes an identifying mark of group affiliation. Language is not merely a vehicle by which I communicate ideas with you, but it constitutes a characteristic in the United States used to categorize who is in and who is out of the "American" group.

52. Morant, supra note 34, at 928.

53. See Matsuda, supra note 1 , at 1402.

54. Schroth, supra note 16 , at 32 . 
The early writings of Benjamin Franklin, in which he "ascribed ignorance and other negative characteristics to those who differed not in knowledge, but in language," 55 are illuminating and set a historical precedent for distinguishing and differentiating between groups based on langnage:

[W]hy should the [German] Palatine Boors be suffered to swarm into our Settlements, and by herding together establish their Language and Manners to the Exclusion of ours? Why should Pennsylvania, founded by the English, become a Colony of Aliens, who will shortly be so numerous as to Germanize us instead of our Anglifying them, and will never adopt our Language or Customs, any more than they can acquire our Complexion. ${ }^{56}$

Extremely xenophobic and fearful of the German "Aliens," Franklin viewed their presence as a threat that would thwart the political process and undermine colonial government. As Juan Perea notes, "This is an early expression of a fear often repeated throughout our legal history: the fear that those who are culturally different, those who speak a different language, represent a threat to our government." 57

A trend was already established, then, early in American history, in which language was utilized to differentiate the "foreign" or "alien" from the core culture. In turn, this supposed "foreignness" came to mean a subversion of American government and American identity: "[f]rom a very early age in American politics, many associated 'foreign influence,' foreign national origin, and foreign traits with disloyalty to America and its government. Difference from the core culture was equated with disloyalty." 58 Simply put, anything foreign to the majority culture became un-American, and so any sound other than the predominant English language was not to be heard in American society. A simple proposal to publish documents in non-English languages could be rejected as "unsound in principle, and as utterly subversive of the true doctrine of the country." 59

Not surprisingly, when the United States expanded its borders westward into Spanish-speaking land, the admission of states into the country coincided with the eradication of native languages and the elevation of

55. Perea, supra note 2, at 288 .

56. Id. at 289. Professor Perea observes that "Franklin's negative attitude toward the Germans is particularly obvious in this excerpt, in which he refcrs to them as a 'swarm' and as 'boors,' racially different from the English." Id.

57. Id. at 288 .

58. Id. at 293 (discussing early Federalist strategies of labeling the Republican party as traitors by identifying the Republican party with the French and their foreignness, ethnicity, culture, and language). More recently, this practice has been illustrated in the Wen Ho Lee case. See Miriam Kim, Discrimination in the Wen Ho Lee Case: Reinterpreting the Intent Requirement in Constitutional and Statutory Race Discrimination Cases, 9 AsIAN L.J. 117, 127-34 (2002).

59. Perea, supra note 2, at 306 
English. ${ }^{60}$ Close to the time it was internally establishing English as the American language, the government was also imposing new laws at the borders that had a significant impact on the institutionalization of English as the language of the country. Until the $1880 \mathrm{~s}$, immigration to the United States remained largely open and unrestricted, and did not pose a concern because most of the immigrants until this time were from northwestern Europe, which were traditional sources of the American population. ${ }^{61}$ In other words, their racial and cultural characteristics matched those of the existing population relatively well, and they were able to assimilate with little cultural friction. However, around 1890 , immigration patterns took a different turn:

[I]mmigrants from these countries began to be out-numbered by immigrants from the countries of southern and eastern Europe: Italy, Poland, and the Austro-Hungarian empire. These new immigrants brought with them their distinctive cultural traits. In response to these new, culturally different immigrants, a strong popular movement, fueled by American nativism, developed in favor of restrictions on immigration to the United States. ${ }^{62}$

A literacy test became the first restriction on immigration, ${ }^{63}$ and immigrants were expected to accept the powerful "myth of linguistic homogeneity ... that allows many people to regard English as the only true American language." ${ }^{64}$ Upon entering the country, the pervasiveness of the English language and the operation of laws written in English further impressed upon the immigrant the dominance and authority of the English language. ${ }^{65}$

Although in practice such a restriction may appear rational, the symbolic implication of an English literacy requirement for naturalization cannot be underestimated because it is in the naturalization laws that the

60. For example, New Mexico was not allowed to become a state, despite several attempts to achieve statehood beginning in 1850, until 1912, "when a majority of its population was Englishspeaking for the first time." Id. at 321. In California, although the constitution in 1849 provided for the official recognition of Spanish and English through the promulgation of the laws in both languages, the White settlers who came looking for gold soon developed "much ambivalence toward the Californios and their Spanish language," and by 1879, fully gripped by "Hispanophobia," prohibited the publication of the laws in any language other than English. Id. at 317-19.

61. Id. at 333 .

62. Id. See also Antonio J. Califa, Declaring English the Official Language: Prejudice Spoken Here, 24 HARV. C.R.-C.L. L. REv. 293, 297 (1989).

63. Professor Perea's research establishes that the government at the time understood that language, in the form of literacy tests, was being employed as a proxy for exclusion on the basis of national origin. President Taft vetoed the literacy test, rejecting it as an indirect, disguised device for the exclusion of a large proportion of immigrants from certain undesirable communities, based on national origin. However, Congress enacted the provision over both President Taft's and President Wilson's vetoes on the eve of America's entry into World War 1, thereby establishing a precedent for the use of language ability as a proxy for national origin. See Perea, supra note 2, at 334-36.

64. Id. at 272 .

65. Id. at 313 . 
criteria for belonging in the United States are most clearly declared. The very existence of a literacy test establishes the "official" character of the language and reifies the notion that the United States is an Englishspeaking culture and that its citizens will have to learn English in order to participate fully in it. ${ }^{66}$ Combined with more recent efforts to explicitly make English the official language, ${ }^{67}$ non-English speakers receive a clear message that they do not belong in America until and unless they speak English. Non-English-speaking immigrants essentially enter a social system in which their mere presence becomes a threat to the national identity, and they in turn become targets of greater English-language vigilantism. ${ }^{68}$

At the same time, proponents of the supremacy of the English language insist that language is a neutral feature and that English should be the language of choice because of its primacy in American society. Advancing the argument that English is undeniably the dominant language of American society, supporters of English-only policies utilize a rhetoric of neutral, culture-based assertions about the unifying benefits of a common language and the necessity of monolingual laws for creating political stability and public confidence. ${ }^{69}$ However, these assertions that multilingualism undermines American society are very much unfounded. Will Kymlicka points out:

To be sure, [ethnic minorities] want the mainstream institutions in their society to be reformed, so as to accommodate their cultural differences, and to recognize the value of their cultural heritage. But the desire for such [minority] rights is a desire for inclusion which is consistent with participation in, and commitment to, the mainstream institutions that underlie social unity. ${ }^{70}$

In stark contrast to claims that non-English languages threaten American stability and unity, racial-language minorities have exhibited a commitment to the institutions of this country, including perhaps most fundamentally its economic institutions. ${ }^{71}$

More importantly, despite the rhetoric of neutrality asserted by English-only proponents, language in actuality is by no means neutral, but

66. Id. at 338 (citing Arnold H. Liebowitz, English Literacy: Legal Sanction for Discrimination, 45 Notre Dame L. Rev. 7, 14 (1969)).

67. The 1980s and 1990s saw a revived interest in and support for state-sponsored comprehensive English-language laws. See Bender, supra note 5, at 1047.

68. See Arington, supra note 13, at 344-47. The author identifies English-only laws passed by direct legislation, that is, by initiative and referendum, as declarations of popular will, and argues that direct legislation is not the appropriate medium by which language laws should be implemented. $I d$. at 347. In contrast to legislation enacted by a representative body where there is often debate and compromise before a vote is taken, the author notes that direct legislation requires a yes or no vote, an all or nothing decision on a question formulated by sponsors alone, resulting in laws which are more extreme and eonflicting than they should bc. $I d$. at 345 .

69. See Serrano, supra note 13, at 226, 230; Califa, supra note 62, at 294.

70. Will Kymlicka, Multicultural Citizenship 178 (1995).

71. See supra Part I. 
is political: "A language is a dialect with an army and a navy." Even where official English-only rules have not been instituted, the established pecking order of languages in America proclaims unambiguously to all, especially to non-English speakers, the social standing of the speakers:

The status hierarchy of languages actually reflects social facts, not linguistic ones. The source of a dialect's status is the status of the dialect's speakers, not the dialect's inherent qualities. Nonstandard dialects are those whose speakers have been relegated to marginal positions in their societies: "[a]s has always been the case in the United States ... those who are in positions of political power and social control dictate the standards of linguistic acceptability."73

Professor Perea accordingly warns that "when language policies establish boundaries between people and government the effects are likely to be quite significant: alienation, distancing, and political impotence." ${ }^{.74}$

The dominance of the English languagc, combined with its acceptance as the "natural" language of American public discourse, obscures the degree to which language defines which groups are within and which are outside of the national identity. Although the use and promotion of the English language can be self-affirming for members of the dominant culture, the coercive nature of sanctioning and reinforcing only the language and ethnic traits of the dominant culture to the exclusion of different, but equally American, languages results in great inequality. ${ }^{75}$ Effectivcly relegating non-English speakers to second-class status, an English literacy requirement, even if unofficial, restricts a non-English speaker's ability to fully participate in the political and social processes of their communities. ${ }^{76}$

More sinister, however, this "great inequality" is compounded by "the iron fist of prejudice and discrimination," hiding behind the rhetoric of

72. Jill Gaulding, Against Common Sense: Why Title VII Should Protect Speakers of Black English, 31 U. MICH. J.L. REFORM 637, 656 (1998).

73. Id. at 657 (quoting John Baugh, Black Street Speech: 1Ts History, Structure, and Survival 30 (1983)); see also Rebeeca Tsosie, Sacred Obligations: Intercultural Justice and the Disclosure of Treaty Rights, 47 UCLA L. REv. 1615, 1655-56 (2000) (quoting IRIS MARION YounG, JUSTICE AND THE POLITICS OF DifFerenCe 58 (1990) (describing "cultural imperialism" and what it means "to experienee how the dominant meanings of a society render the partieular perspeetive of one's own group invisible at the same time as they stereotype one's group and mark it out as the Other")).

74. Perea, supra note 2, at 355 (quoting William O'Barr, Boundaries, Strategies, and Power Relations, in Language and Politics 414 (William O'Barr \& Jean O'Barr eds. 1976)).

75. See id. at 365-66.

76. See Serrano, supra note 13, at 261 (noting that "the sweeping prohibition of non-English languages would exclude undesirable immigrant groups from all realms: politieal (communication with representatives, reading and understanding ballots), state governmental (applications for benefits, directions for filing complaints and obtaining permits) and social (directions to clinics or sehools, tourism brochures)"); Arington, supra note 13, at 341 (noting that "broadly applied English-only laws may still have tremendous impact on the lives of non-English speakers because federal laws protecting language minority rights, important as they may be, provide only limited protection to non-Englishspeaking citizens"). 
neutrality. ${ }^{77}$ How do we get from language to discrimination and prejudice? First, as already shown, language is not a neutral feature of an individual's identity. Rather, when we speak of language in relation to the dominance of English, we often discuss it as a marker of racial-group identity. The resurgent interest in making English the official Amcrican language is understood as a xenophobie response to the presence of the large, and largely unwelcome, volume of immigration of many Latinas/os and Asians during recent decades who have changed "the racial and cultural balance carefully preserved by the prior quota system [in immigration laws]." scholar has noted, "Given the huge numbers of immigrants who enter this country from Asian and Latin American countries whosc citizens are not white and who in most cases do not speak English, criticism of the inability to speak English coincides neatly with race."79 The threat perceived by English-only proponents is not the threat of Spanish, Chinese, Korean, or Vietnamese as languages, but rather the menace of Latinas/os and Asians whose growing numbers pose a political threat. ${ }^{80}$

Even courts that appreciate monolingualism for the purpose of unity have not failed to perceive the material effects of English-only legislation and the resultant allocations of resources and opportunities along racial lines. For example, in Yniguez v. Arizonans for Official English, ${ }^{81}$ the Ninth Circuit hcld that there was a "critical difference between encouraging the use of English and repressing the use of other languages," and that "the

77. Califa, supra note 62, at 294.

78. Perea, supra note 2, at 343-44; see also Serrano, supra note 13, at 228 n.56 ("Commentators have recognized that English Only arguments are often directly connected to those made by antiimmigrant groups.").

79. Bill Ong Hing, Beyond the Rhetoric of Assimilation and Cultural Pluralism: Addressing the Tension of Separatism and Conflict in an Immigration-Driven Multiracial Society, 81 CALIF. L. REv. 863,874 (1993). Susan Serrano also comments that the national anti-immigrant backlash against providing welfare to legal and illegal immigrants, the move to abolish affirmative action, and the call to deny health eare and education to illegal immigrants reflect the underlying fear that "immigrants will leave their nonwhite mark on the Ameriean landscape." Serrano, supra note 13, at 227 (quoting Hing, supra).

80. See Califa, supra note 62 , at 326-28. The history of the most visible special-interest group advocating the offieialization of the English language, U.S. English, reveals the movement's racist paranoia concerning non-English speakers. For example, in 1985, that organization lobbied the Federal Communications Commission to adopt a rule limiting the number of Spanish-language stations in south Texas because of what it perceived as a "systematic displacement of English-language radio stations in the Texas border counties." See Averbach, supra note 13, at 501. The organization has been repeatedly accused of racist tactics and propaganda. See id.; see also Perea, supra note 2, at 345-46 (quoting from an infamous memo by Dr. John Tanton, founder and former chairman of U.S. English, expressing "his grave eoncerns about Hispanic fertility and reproduction, Catholicism, and the threat that Hispanics pose to white Anglo dominance of American society").

81. 69 F.3d 920 (9th Cir. 1995) (en banc), cert. granted, 517 U.S. 1102 (1996), vacated and remanded, 520 U.S. 43 (1997) (finding that plaintiff Yniguez's changed circumstances-her resignation from the public sector employment (targeted by the English-only law at dispute) to pursue private sector work-mooted the case stated in her complaint, thus requiring the Court to vacate the lower court's judgment and remand the case with directions that the action be dismissed by the District Court). 
adverse impact of the [English-only law's] over-breadth is especially egregious because it is not uniformly spread over the population, but falls almost entirely upon Hispanics and other national origin minorities. ${ }^{982} \mathrm{By}$ allocating resources along racial lines, the culture-based arguments offered by proponents of English-only laws contain implications that are distinctly race-based. Culture and language become a cloak for race. ${ }^{83}$

At the same time, because "the racial and cultural differences of recent immigrants from the core culture have not gone unnoticed," Asian- and Spanish-speaking immigrants become targets for nativist movements that disenfranchise and "seek to reinforce their narrow view of American cultural identity through the law by restricting cultural traits deemed 'foreign." "85 Rather than representing a neutral feature of an ethnic group's culture, language has become a significant political device for the dominant group and, like anything else political, it is related to the distribution of power and access in our society. In post-Civil Rights Movement America, language becomes as significant as skin color in separating out the privileged groups from the not-so-privileged groups, ${ }^{86}$ and racial hierarchy functions by excluding those who do not physically conform to whiteness as well as those who are perceived as unassimilable and unfamiliar with the dominant culture. ${ }^{87}$ Spanish- and Asian-language speakers thus

82. Yniguez, $69 \mathrm{~F} .3 \mathrm{~d}$ at $923,947$.

83. Serrano, supra note 13, at 245-46. Opponents may disagree that current language and immigration policies function along racial lines, pointing to the experience of other White immigrants in American history, namely Germans. During World War l, "Germans were deemed disloyal merely for being, acting, speaking, and reading like Germans.... The wartime nativism led to the imprisonment, public flogging and lynching of Germans." Id. at 329-30. However, after the war, due to nativism and its resultant "killing" of German culture in American society, and more significantly "the embrace of white supremacy as ideology and as practice [as] a strategy for assimilation by European working class immigrants," Germans and other White immigrants have assimilated into "America" and currently enjoy the privileges that come with white skin. Kimberlé Williams Crenshaw, Race, Reform, and Retrenchment: Transformation and Legitimation in Antidiscrimination Law, 101 HaRv. L. Rev. 1331, 1375 n.168 (1988) (quoting Herbert Hill, Race and Ethnicity in Organized Labor: The Historical Sources of Resistance to Affirmative Action, J. INTERGROUP REL., Winter 1984, at 6).

84. Perea, supra note 2, at 344-45.

85. Id. at $340-41$.

86. Professor Matsuda comments on language as a modern marker used to maintain social distinctions:

The recent push for English-only laws, and the attack on bilingual education, may represent new outlets for racial anxiety now that many traditional outlets are denied. The angry insistence that "they" should speak English serves as a proxy for a whole range of fears displaced by the social opprobrium directed at explicit racism.

Matsuda, supra note 1, at 1397.

87. See Espinoza \& Harris, supra note 15, at 10 LA RAZA L.J. 541, 553-54, 85 CALIF. L. Rev. $1627,1639-40$ (rejecting the focus on skin color as the essence of racial discrimination and proposing that racial hierarchy is preserved by the maintenance of White cultural norms, including language, to which all groups should assimilate, the failure of which results in racialization of those groups); see also Tsosie, supra note 73, at 1655-59 (examining how the dominant group universalizes its experience and culture and establishes them as the norm, and how culture informs how dominant groups think and act about race). 
experience America not merely as non-English speakers, but as raciallanguage minorities who face unequal treatment when seeking government services, employment opportunities, and economic protection. ${ }^{88}$

The move by scholars to align language issues with race is thus crucial and fitting. As Ian Haney-López explains, "Because race is so deeply embedded in this society, its reach and effects must be addressed in terms of race itself-there is no better, indeed, no other language available to us. ${ }^{~}{ }^{89}$ Further, because the reach and effects of race are often conceived of as far removed from race, it is necessary to bring people's attention to language discrimination as a potential form of racism. Fortunately, American society has progressed to a state in which overt displays of racism have largely been eradicated. Racism persists, however, and in the place of overt violence we currently encounter subtler and more concealed manifestations of discrimination and prejudice. More so than ever, then, using the "language of race... directs attention to racial oppression's long-term effects on the day-to-day conditions encountered and endured by racialized communities." ${ }^{90}$ Using the language of race and the construct of language as race enables us to argue that as racialized communities, racial-language minorities are entitled to protection against discrimination and prejudicial policies that disproportionately allocate benefits and risks:

Of course, while language preferences generate social injustice in the form of discrimination and prejudice, they also inhibit and suppress the racial-language minority's power to assert her rights. Racial-language minorities associate the predominance of the English language with a public opinion that any other language is necessarily inferior and un-American. ${ }^{91}$ The climate created by official English-only movements and the widespread assumption of the English language as the "normal" language of American society causcs immigrants, whether "documented or not, to avoid dealing with the government for fear of harassment or abuse. ${ }^{, 92}$

88. See generally Bender, supra note 5; Serrano, supra note 13, at 261 (observing that "the sweeping prohibition of non-English languages would exclude undesirable immigrant groups from all realms: political (communication with representatives, reading and understanding ballots), state governmental (applications for benefits, directions for filing complaints and obtaining permits) and social (directions to clinics or schools, tourism brochures)").

89. Ian F. Haney-Lópcz, Race, Ethnicity, Erasure: The Saliance of Race to LatCrit Theory, 10 LA RAZA L.J. 57, 101-102 (1998), 85 CALIF. L. Rev. 1143, 1187-88 (1997).

90. Id. at 10 La Raza L.J. 111, 85 Calif. L. Rev. 1197.

91. See Califa, supra note 62 , at 324. Califa states:

$[\mathrm{M}]$ inority-language communities view sueh legislation as stigmatizing and as an expression of xenophobia.... Hispanics are concerned that the English Only movement is an attempt to brand Hispanics as inferior and un-American.... The fears and prejudices of English Only Id. proponents in the United States can create the very divisiveness they purport to avoid.

92. Bender, supra note 5, at 1036. Professor Bender thus worries that "[a]busive market practices thrive in this anti-immigrant climate." Id. He urges "aggressive public enforcement against language fraud practiced on Spanish-Only Consumers [to] send merchants the more general message that there is no open season on Latinos/as." Id. at 1061. 
Burdened with this perception, it is not surprising if the persons in most need of legal assistance are reluctant to incur the costs of retaining such aid to pursue a legal claim against practices that carry a disparate impact on non-English speakers. Studies have shown that private citizens in general grossly overestimate the costs of obtaining counsel to represent their causes. ${ }^{93}$ Unfamiliar with the legal system and overwhelmed by the situation in which they find themselves because of their language barriers, many racial-language minorities may prefer privately absorbing the damages rather than losing more money on a legal action brought before an unsympathetic audience. Racial-language minorities thus find themselves in a tight bind as the coercive strength of the English language's dominance renders them inferior and posits them as weak and powerless to the effect that members of racial-language-minority communities dare not speak up:

[W] hen you are powerless, you don't just speak differently. A lot, you don't speak. Your speech is not just differently articulated, it is silenced. Eliminated, gone. You aren't just deprived of a language with which to articulate your distinctiveness, although you are; you are dcprived of a life out of which articulation might come. ${ }^{94}$

Language then becomes an exercise about power, and language policies throughout the various arenas of American social life essentially license the disempowerment of racial-language minorities. In this respect, the avoidance of racial-language issues by contract law is inexorably critical to the exercise and distribution of economic power. The correlation betwecn language and race not only facilitates a contextual analysis for explaining the lack of language-based claims in contract law, but also illuminates an actual inaccessibility of a legal system —one which purports to uphold the economic rights of its participants-to those whose economic rights are regularly challenged. By avoiding the language-based issues of

93. See, e.g., Bates v. State Bar of Ariz., 433 U.S. 350 (1977). The Court noted that "[s]tudies reveal that many persons do not obtain counsel even when they perceive a need because of the feared prices of services or because of an inability to locate a eompetent attorney." Id. at 370 . The Court further quoted from The Report of the Special Committee on the Availability of Legal Services, adopted by the House of Delegatcs of the American Bar Association, and contained in ABA's Revised Handbook on Prepaid Legal Services:

We are persuaded that the actual or feared priee of such services coupled with a sense of unequal bargaining status is a significant barrier to wider utilization of legal services. ... There are indications that fear of cost is unrealistic ... (reporting study in which middle class consumers overestimated lawyers' fees by $91 \%$ for the drawing of a simple will, $340 \%$ for reading and advising on a 2-page installment sales contract, and $123 \%$ for 30 minutes of consultation).

Id. at 370 n.22 (quoting ABA's Revised Handbook on Prepaid Legal Services 26 (1972)).

94. Catharine A. MacKinnon, Feminism Unmodified: Discourses on Life and Law 39 (1987); see also Perea, supra note 2, at 352 ("Discourse itself, the expression of ideas, and the ordering of discourse, who gets to express ideas, who gets to express them first, and which ideas get expressed, also reflect hierarchy and relationships of power in society."). 
Spanish- and Asian-language-speaking business owners, contract law unavoidably upholds and endorses the pro-English norm, furthering the disempowerment of these racial-language minorities.

At the same time, the provision of contracts and form terms in English, a language widely unavailable to many recipients of form contracts, generates considerable suppression-suppression not only of information, that is, the terms of the contract, but more troubling than that, suppression of the person's ability to assert her claims through the law. As Kimberlé Crenshaw points out, "People act out their lives, mediate conflicts, and even perceive themselves with reference to the law." If this is so, though, what impact will there be on the lives of racial-language minorities when the law consistently denies their relevance and recognizes only the legal weight of the English language? In other words, the problem is not merely limited to the fact that a racial-language minority will encounter more difficulty in ascertaining the meaning of the contract terms. The ubiquity of English in contract and market transactions is at least equally disempowering-it reminds racial-language minorities that English is championed as the language of American society, rendering all other languages irrelevant, if not objectionable. To bring a language-based claim disputing the validity of a term provided in the drafting party's English form, the racial-language minority now must overcome a societal hurdle in addition to the doctrinal hurdles engendered by her legal claims; she not only deals with the law, but also she deals with the law as seen predominantly through English-tinted lenses. In sanctioning an English-only practice that necessarily neglects the language rights of non-English speakers, contract law thus implicitly reinforces the supremacy of the English language.

More simply stated, contract law is directly implicated in the maldistribution of economic rights based on race. Despite contract law's pretensions of disengagement, race discourse is relevant to discussions about market transactions. Contract law must therefore take on the heady social justice concerns that inescapably engage it.

III

Contract LaW's Recognition of the Economic Rights of RacialLANGUAGE MiNORITIES

Having established the extent to which contract law evades questions of race and social justice, and thereby providing an explanation for the lack of language-based contract disputes, I now turn to the ways in which contract law could more fully address the impact of language barriers in the bargaining process. This following Part surveys the current state of

95. Crenshaw, supra note 83 , at 1351-52. 
contract law's recognition of minority language rights, encapsulated primarily in the fraud and unconscionability doctrines, and examines the limitations of these approaches in sufficiently accounting for marketplace inequities. The application of assent-based methods in contract law is thereafter proposed as an alternative avenue for ameliorating the languagebased challenges encountercd by small-business owners in the pursuit of thcir economic and business claims. Although the practicability of assentbased methods has yet to be tested, doctrinally the assent-based methods offer a promising basis upon which the business and economic rights of racial-language minorities may be upheld, and they may cven legitimate a legal imperative to provide contracts in the small-business owner's Spanish or Asian language.

\section{A. The Current State of Contract Law's Recognition of Language-Based Disputes}

To some extent, and perhaps to a significant extent, contract law has acknowledged language-barrier issues in disputes between English speakers and non-English speakers. Predominantly in the consumer and employment contract contexts, many of the reported decisions dealing with language-based disputes were issued by the lower courts of the 1960s and 1970s, during the prevalence of public legal aid. ${ }^{96}$ These cases often involved Spanish-speaking consumers who agreed to contracts that were presented in English only, contained unfair terms for the consumer, and were never translated nor cxplained to the consumer. ${ }^{97}$ These consumers, required to sign agreements that they could not read for the purpose of transacting, were rendered "handicapped by a lack of knowledge, both as to the commercial situation and the nature and terms of the contract which was submitted in a language foreign to them." 98

When subjcct to unscrupulous merchant practices, the doctrine of fraud provided one basis of protection for a non-English speaker against exploitation based on her language skills. A contract would be rendered null and void where there existed evidence of fraudulent misrepresentations by English-speaking parties to non-English-literate parties about the terms of their contract. ${ }^{99}$ The problem with fraud, however, is that the

96. Bender, supra note 5, at 1041 .

97. For consumer cases, see, for example, Frostifresh Corp. v. Reynoso, 274 N.Y.S.2d 757 (Dist. Ct. 1966), rev'd on other grounds, 281 N.Y.S.2d 964 (N.Y. App. Term 1967), and Brooklyn Union Gas Co. v. Jimeniz, 371 N.Y.S.2d 289 (N.Y. Civ. Ct. 1975). For cases involving languagc barriers within an employment contraet setting, see, for example, Retana v. Apartment, Motel, Hotel \& Elevator Operators Union, 453 F.2d 1018 (9th Cir. 1972), and Prevot v. Phillips Petroleum, 133 F. Supp. 2 d 937 (S.D.Tex. 2001).

98. Frostifresh, 274 N.Y.S.2d at 759.

99. See, e.g., Cancanon v. Smith Barney, Harris, Upham \& Co., 805 F.2d 998 (11th Cir. 1986) (in which non-English-literate plaintiffs were misled into signing securities agreements which were presented to them in English). 
claim requires evidence of active or affirmative misrepresentation, which may not always be present. ${ }^{100}$ Moreover, fraud does not directly address the language rights of the racial-language minority. The existence of a language barrier cannot in and of itself constitute fraud. Rather, language barriers simply make easier the commission of fraud on innocent parties. ${ }^{101}$

An alternative and more readily applicable doctrine applied by courts in protecting racial-language minorities against exploitation has been unconscionability. The imposition of English contracts which were never translated nor explained to the non-English-speaking consumers has been found by many courts to be "oppressive," "shocking to the conscience," and thus unconscionable. ${ }^{102}$

Unconscionability is a fairly modern doctrinal development in contract law, typifying contract law's shift away from a classical theory of contracts based on freedom of contract and autonomy rationales. The most durable definition of unconscionability, provided in Williams $v$. WalkerThomas Furniture, ${ }^{103}$ sets out a procedural and substantive prong to the analysis: "Unconscionability has generally been recognized to include an absence of meaningful choice [procedural] on the part of one of the parties together with contract terms which are unreasonably favorable [substantive] to the other party."104 Essentially, the basic test of unconscionability is whether, "in light of the general commercial background and the commercial needs of the particular trade or case," the clauses involved are so one-sided as to require a more equitable reformation of the contract. ${ }^{105} \mathrm{~A}$ contract is unconscionable if it "is unfair because of its overall one-sidedness or the gross one sidedness of one of its terms." court in Brooklyn Union Gas Co. v. Jimeniz explained, "The basic test of unconscionability of a contract is whether under the circumstances existing at the time of the creation of the contract the parties were in equality to each other on all levels." 107 Where a contract dispute involves language barriers, a court "can look into the contract to make its determination and ascertain how the contract was printed, whether both parties to the contract spoke English, how the contract was made and if the contract was onesided." 108

The unconscionability doctrine has been very useful in consumer and employment contexts, where non-English speakers often engage with more

100. Bender, supra note 5, at 1039.

101. See Cancanon, 805 F.2d 998.

102. Frostifresh, 274 N.Y.S.2d at 759.

103. 350 F.2d 445 (1965).

104. Id. at 449.

105. E. Allan Farnsworth, Farnsworth on Contracts 55 (2d ed. 1998).

106. Prevot, 133 F. Supp. 2d at 940 (quoting Pony Express Courier Corp. v. Morris, 921 S.W.2d 817, 821 (Tex. App. 1996)).

107. Jimeniz, 371 N.Y.S.2d at 290.

108. Id 
powerful companies and corporations. The power differentials inherently involved in consumer and employment contexts ease a court's finding of unconscionability - the already existing unequal bargaining power is merely aggravated by the fact that the weaker party cannot speak English. ${ }^{109}$ The correlating problem is that, while the inherent power differentials facilitate a finding of unconscionability in favor of the raciallanguage minority, they can, and often do, overshadow the language rights at issue.

Under an unconscionability analysis, a language barrier will often be analyzed as evidence of procedural unconscionability. However, a court might not need to weigh it heavily, or at all, depending on the strength of other features of procedural unconscionability, such as the offeror's unfair sales technique, or the offeree's isolation and general ignorance of the market, her inexperience and lack of education, or her age (if very young or very old). Moreover, when there is overwhelming evidence of substantive unfairness, as in Frostifresh Corp. v. Reynoso, where the service charge alone almost equaled the price of the appliance and was to the court "in and of itself indicative of the oppression which was practiced on these defendants," the conditions supporting procedural unconscionability, including language barriers, tend to lose emphasis in the analysis. ${ }^{110}$ Stephen Bender notes that some "commentators sometimes cite [Frostifresh] as authorizing courts to declare a contract unconscionable on substantive unfairness alone," "11 completely bypassing the language-barrier factor. In application, then, unconscionability addresses language barriers and racebased elements indirectly, perhaps even evasively. In so doing, contract law again reifies the classical theory which filters out social factors such as race from the realm of contract law. ${ }^{112}$

109. See id.

110. Frostifresh, 274 N.Y.S.2d at 759 . 1t has been held that there is a "sliding seale relationship" between procedural and substantive uneonseionability: "the greater the degree of substantive uneonscionability, the less the degree of procedural unconscionability that is required to annul the contract." Carboni v. Arrospide, 2 Cal. App. 4th 76, 83 (Cal. Ct. App. 1991).

111. Bender, supra note 5, at 1041 . He continues, "Unconscionability... does not yet grant relief for proeedural unfairness standing alone that lacks a separate and established basis for relief, as when there is duress or fraud." Id. at 1043; see also Communications Maintenance v. Motorola, 761 F.2d 1202,1210 (7th Cir. 1985) (explaining that where there is "no substantive unconscionability we do not reach the issue of whether there was procedural unconscionability").

112. As mentioned earlier, Williams v. Walker-Thomas Furniture Co., 350 F.2d 445 (1965), demonstrates the escape door provided in unconscionability for contract law to evade issues of race. Instead of explicitly acknowledging that the plaintiff was an African American woman on government assistance, faetors that undoubtedly may have affected the contractual behavior of the parties, the court couched its unconscionability analysis in terms of whether there could be found a gross inequality of bargaining power and absenee of meaningful choice for the plaintiff. Id. at 449 . There is no mention of her race at all as relevant to the faimess analysis. On the other hand, even if the court had acknowledged the plaintiff's race, it is likely that such identification would have only supported the weight of procedural uneonscionability. As potentially one of multiple factors for the court to eonsider 
When conceptualizing unconscionability as a defense to contract enforcement, the unconscionability doctrine further ignores the importance of language and race. A court may nullify or reform a contract if it is found to be unconscionable, but to get to an unconscionability analysis at all, there has to be valid contract formation in the first place. ${ }^{113}$ Todd Rakoff describes unconscionability as a concept "that by its very nature seems to assume the presumptive enforceability of the [contract] at issue." ${ }^{.14} \mathrm{Al}$ though by their very nature language barriers interfere with and oppose contract formation, an unconscionability analysis that might consider language barriers requires the formation of the contract at issue and presumes its enforceability. Language issues and race concerns thus become doubly removed from the analysis; not only is a language barrier an extraneous factor to consider under unconscionability, but it only comes into the picture when unconscionability is raised as a defense to contract enforcement. Thus far, courts have not sufficiently addressed the presence of language barriers as a factor undermining contract formation when inquiring into whether a meeting of the minds between the parties took place at all. ${ }^{115}$

At a practical level, in addition to its avoidance of race and language discussion, the unconscionability doctrine also may be ineffective in adequately deterring the injurious conduct. Courts not only have declined to award tort remedies, such as punitive damages, but also have refused to award restitution and other affirmative damages. ${ }^{116}$ In consumer cases, courts at most limit the merchant's bargain to the fair price it should have charged and will not rcquire the merchant to return any overpayment. ${ }^{117}$ Unconscionability thus offers a limited protection of the economic rights of language minorities.

Lastly, and most pertinent to the unique needs associated with immigrant proprietorship, unconscionability as a protective device for the economic rights of racial-language minorities proves to be all the more problematic when considering parties outside of employment or consumerlike settings. Because the basic test of unconscionability asks whether

in its unconscionability analysis, race loses its significance and could be included or excluded in the analysis, depending on the relative weight of other procedural unfairness evidence.

113. See Jimeniz, 371 N.Y.S.2d at 290.

114. Todd D. Rakoff, Contracts of Adhesion: An Essay in Reconstruction, 96 Harv. L. Rev. 1173,1192 (1983).

115. See, for example, Nguyen Ngoc Giao v. Smith \& Lamm, P.C., 714 S.W.2d 144 (Tex. App. 1986), in which the language minority attempted to argue that the language barrier created a meeting of the minds issue but abandoned the argument on appeal, likely anticipating the appellate court's application of the "well settled" rule "that illiteracy will not relieve a party of the consequences of his contract." Id. at 146.

116. See Bender, supra note 5, at 1042.

117. See id; see also Farnsworth, supra note 105, at 555 (noting that "courts have declined... to entertain damage suits based on unconscionability" and instead cast remedies for unconscionability "in terms of withholding relief instead of avoidance, [so that] there is no inherent requirement that the claimant make restitution"). 
under the circumstances existing at the time of contract formation the parties were equally positioned to each other on all levels, the more "equal" the parties appear, the less unconscionability plays into the analysis. Where the inequality between parties arises solely from a language barrier, the defense of unconscionability is left on the shelf. Professor Farnsworth noted:

It is not surprising that most of the parties that have successfully invoked the doctrine of unconscionability have been consumers. . . . Many courts, however, have not shared this attitude toward franchisees. And courts have generally been chary about using the doctrine of unconscionability to protect merchants and similar professionals. ${ }^{118}$

Thus, between parties who function at a fairly even bargaining level, such as racial-language business owners contracting with commercial suppliers and vendors, unconscionability may be inapplicable. Discussions of issues peculiar to disadvantaged groups therefore cannot be confined to unconscionability. ${ }^{119}$

Accordingly, by addressing the particular needs of market actors who are on a relatively equal footing with their English-speaking counterparts, we may more fully protect the economic rights of racial-language minorities. As self-employed proprietors contracting with English-speaking vendors and suppliers, immigrant small-business owners offer a compelling contractual relationship through which a more comprehensive vision of minority economic rights may be asserted. Routinely entering into contracts with their vendors and suppliers based on English-language form contracts provided by the English-speaking vendor or supplier, these minority proprietors encounter unique language-based challenges to their economic rights. If dissatisfied with the level of performance on the part of her English-speaking vendor or supplier, who perhaps may have provided less than satisfactory services or a defective shipment of requested products, the language minority's sole recourse may be to point to the form document that constitutes the initial basis of their contractual relationship and dispute the presumption of her assent to unfavorable terms.

118. FARNSWORTH, supra note 105, at 563-64; see also WXON-TV v. A.C. Nielson Co., 740 F. Supp. 1261, 1264 (E.D. Mich. 1990) (stating that "law presumes that business people are fully competent to enter into contracts ... in any manner they wish"), on reconsideration, $742 \mathrm{~F}$. Supp. 418 (E.D. Mich. 1990); Stirlen v. Supercuts, Inc., 60 Cal. Rptr. 2d 138, 146 (Cal. App. 1997) (contrasting professional employee from "a person desperately seeking employment"); Equitable Lumber Corp. v. IPA Land Dev. Corp., 344 N.E.2d 391, 396 (N.Y. 1976) (finding that contract between builder and lumber provider was one between "commercial entities dealing at arm's length with relativc cquality of bargaining power").

119. Morant, supra note 34, at 896. As Professor Morant notes, regulatory devices such as unconscionability "cannot, by themselves, sufficiently accommodate marketplace inequities. The very dearth of cases where individuals are successful in obtaining relief through those devices substantiates this point." Morant, supra note 38, at 110. 


\section{B. Assent-Based Approaches for Upholding the Economic Rights of Racial-Language Minorities}

The following discussion analyzes available assent-based methods and their applicability to language-barrier cases as a means of providing greater protection for immigrant small-business owners, as well as for racial-language minorities in general. The notion of assent, though tricky in modern commercial realities, remains a central tenet not only for contract formation, but also for determining the coverage and boundaries of the contract. It seems appropriate, then, to address the nature of a raciallanguage minority business owner's assent to the English-speaking vendor's form terms when examining each party's risks and responsibilities under the contract.

Applying assent-based methods provides protection in several noteworthy ways. In addition to better equipping the racial-language minority business owner to pursue her economic claims upon the vendor's deficient performance, assent-based methods might engender precontract formation protection by possibly requiring the provision of translated form documents. Assent-based methods are preferable to applying an unconscionability test because an assent-based inquiry directly involves the language barrier in its analysis, explicitly addressing the racial-language minority's language rights. In so doing, the assent-based methods provide a means by which contract law equally extends its protection of economic and civil rights to racial-language minorities.

To better appreciate the applicability of assent-based methods to the form contract setting between the racial-language minority business owncr and English-speaking vendor, it is important to identify the unique features of form contracts as a contractual device. Unlike traditional contract law, which conceives of an agreement reached by two parties of equal bargaining power by a process of free negotiation, routine transactions in the modern commercial world generated the prevalence of standardized printed forms "prepared by one party and assented to by the other with little or no opportunity for negotiation." 120 The main justification for the form contract-efficiency - was enabled by the "mass production and distribution" of standardized terms. ${ }^{121}$ Releasing the salesman from negotiating the minute details of each individual transaction, form contracts simplify operations and reduce transaction costs. ${ }^{122}$ Moreover, form contracts relieve the higher-up personnel in the organization from having to closely supervise

120. FARNSWORTH, supra note 105 , at 533. The impact of standardization in reducing the possibility of negotiation over terms has prompted the suggestion that in contrast to the movement from "status to contract," which was detected in the late 19th century, there is now a "distinct veering back to status." Id. at 534 (quoting 1saacs, The Standardizing of Contracts, 27 YALE L.J. 34, 40 (1917)).

121. Restatement (SECOND) of Contracts $\S 211 \mathrm{cmt}$ a (1981).

122. Id.; see also Rakoff, supra note 114, at 1222-23. 
and train the employees who will be directly dealing with the customers. When salespeople sell "a standard product at a standard price on standard terms," there is no need for special training, and salespeople become nearly interchangeable, lowering costs for the firm. ${ }^{123}$ Although basic terms relating to quality, quantity, and price might be negotiable, the seller's "boilerplate"-standardized terms printed on the form-is not subject to bargain and must simply be adhered to if the transaction between the buyer and seller is to proceed. ${ }^{124}$ Thus, form contracts often are characterized as "take it or leave it" contracts, or "contracts of adhesion." 25

In general, contract law imposes a strict duty to read or to seek out someone else to read and to translate the contract. ${ }^{126}$ The risk in the context of immigrant small-business owners is thus that the owner will be presumed to have assented to the terms of the English form contract. When faced with a vendor's deficient performance, the owner may feel compelled to accept the enforceability of the standardized terms, especially if reinforced by the English-speaking vendor seeking to avoid liability. Significantly, however, because the main justification for the standardized contract is its efficiency, the rules regarding form contracts are specifically attuned to recognize that form documents are not read by anyone, not even the contracting parties. ${ }^{127}$ The seller does not take the time to go over the boilerplate terms, and the buyer often does not have the time to review the often convoluted and unreadable boilerplate terms before agreeing to the transaction, maximizing the supposed efficiency of the bargaining process. As a result of rules tailored around the acceptance that no one reads form contracts, the racial-language minority business owner's rights no longer strictly depend on whether she read the form before signing or accepting the contract.

Form contracts thus demand a unique understanding of "assent." Although it is presumed that no one reads these form documents, the parties are recognized as having assented to a contractual relationship based on corresponding performance. The rules involving interpretation of form

123. See Rakoff, supra note 114, at 1223.

124. Indeed, it would defeat the purpose of standardization if the other party were free to negotiate over its terms. Id.

125. Typically, contracts of adhesion involve a form document

drafted by, or on behalf of, one party to the transaction.... The drafting party partieipates in numerous transactions of the type represented by the form and enters into these transactions as a matter of routine... The form is presented to the adhering party with the representation that, except perhaps for a few identified items..., the drafting party will enter into the transaction only on the terms contained in the document... The adhering party enters into few transactions of [this] type ..., at least[] in comparison with the drafting party. ., and [t] the principal obligation of the adhering party is the payment of money.

Rakoff, supra note 114, at 1177. Commonplace examples of adhesive form contracts include purchase orders for the sale of automobiles, credit card agreements, and insurance policies.

126. Bender, supra note 5, at 1037-38.

127. See Fuller \& EISEn Berg, supra note 28, at 624. 
contracts lend themselves to upholding the rights of racial-language minorities by adding flexibility to the notion of assent. Although the parties may have broadly assented to the transaction, assent as to specific terms in the form contract may be available for debate. As Karl Llewellyn notably suggested regarding terms communicated by means of preprinted forms:

Instead of thinking about "assent" to boilerplate clauses, we can recognize that so far as concerns the specific, there is no assent at all. What has in fact been assented to, specifically, are the few dickered terms, and the broad type of transaction, and but one thing more. That one thing more is a blanket assent (not a specific assent) to any not unreasonable or indecent terms the seller may have on his form, which do not alter or eviscerate the reasonable meaning of the dickered terms. The fine print which has not been read has no business to cut under the reasonable meaning of those dickered terms which constitute the dominant and only real expression of agreement. ${ }^{128}$

Although the provision of the terms to the business owner may overwhelmingly suggest the owner's assumption of the detailed risks, the four corners of the form document do not constitute the entirety of the contract. By means of the assent-based methods of interpreting form contracts, the business and economic claims available to the aggrieved immigrant business owner may be preserved.

The assent-based methods directly relate to the basic tenet of contract formation that holds that no contract is formed where there is no "meeting of the minds," that is, no mutual assent as to the contract. ${ }^{129}$ The assentbased methods rely on a basic finding "that there is no assent to be bound by the writing, no assent to be bound by particular terms of the writing, or no assent to the meaning of those terms advanced by the author of the writing." 130 Under classical contract law, assent was objectively interpreted; the standard by which a eontract was interpreted was the parties' overt acts, and not the subjective state of the parties' minds. ${ }^{131}$ Modern contract law, however, is amenable to incorporating subjective elements and offers at least two basic assent-based approaches to resolving a form contract dispute: (1) the "principles of interpretation" approach and (2) a "reasonable expectations" test.

At first glance, there are four central principles of interpretation: ${ }^{132}$

1. If the parties subjectively attach different meanings to an expression and the two meanings are not equally reasonable, the more reasonable meaning prevails; ${ }^{133}$

128. Karl llewellyn, The Common law Tradition 370 (1960).

129. FULLER \& EISENBERG, supra note 28, at 348.

130. FARNSWORTH, supra note 105 , at 542-43.

131. Woburn Nat'l Bank v. Woods, 89 A. 491 (N.H. 1914).

132. See FUller \& EISENBERG, supra note 28, at 360. 
2. If the parties subjectively attach different meanings to an expression and the two meanings are equally reasonable, neither meaning prevails; ${ }^{134}$

3. If the parties subjectively attach the same meaning to an expression, that meaning prevails even though it is unreasonable; ${ }^{135}$ and,

4. If the parties, $A$ and $B$, attach different meanings, $M$ and $N$, to an expression, and $\mathrm{A}$ knows that $\mathrm{B}$ attaches meaning $\mathrm{N}$ while $\mathrm{B}$ does not know that $A$ attaches meaning $M$, meaning $N$ prevails even if it is less reasonable than meaning $M .{ }^{136}$

More than the others, Principle 1 provides a compelling basis upon which a racial-language business owner may protect her business interests against an English form contract. In reverse order, Principle 4 is problematic for various reasons. In most cases, it is unclear that the vendor or supplier even thinks about whether the immigrant business owner understands the terms of the form, even if the vendor recognizes a languagc barrier. In any case, it will undoubtedly be difficult, if not impossible, for the raciallanguage minority business owner to prove that the English-speaking supplier knew that the owner understood the terms of the contract differently from how they were intended. The evidentiary problems that are likely to arise make this approach largely unrealistic for the adhering business owner.

Principle 3 is inapplicable in the case of the immigrant business owner seeking to invalidate a term to which she did not assent, since its application requires that both parties agree on the meaning. Principle 2 comes closer, but it remains problematic because it asks if two different meanings are equally reasonable and invalidates both meanings if that is the case. Essentially, when English forms are pressed upon racial-language minorities, the form drafter's "meaning" of the contract is ostensibly encapsulated in the terms of the form document. However, for the racial-language minority unable to read and understand the form terms, the meaning of the contract is manifested in the relationship established with the vendor or supplier- "I will pay and you will perform by delivering on time."

These two varying meanings are not equally reasonable, for the former requires an objective reading, and the latter requires a slightly more subjective one. If it is more reasonable to expect the parties to be bound by the terms set forth in the written document, this conclusion could only

133. Id. This principle is adopted in Restatement (SECOND) OF CONTRACTS § 201(2)(b) (1989).

134. Id. at 361. This principle is adopted in Restatement (SECOND) OF CONTRACTS $\$ 201$ (1989) and is reflected in Raffles v. Wichelhaus, 2 Hurl. \& C. 906 (Ex. 1864).

135. Id. at 362 .

136. Id. at 363. This principle is adopted in Restatement (SECOND) of Contracts $\S 201$ (2)(a) (1989). 
stand under classical contract law. Under modern contract law, however, it seems unreasonable to impose a duty upon the racial-language minority to abide by the written terms when such terms are available only in English, are drafted by and exclusively in favor of the vendor, and are neither explained nor translated to her. This seems especially true when the vendor knows that the business owner to whom the form is presented does not speak nor read English very well.

Principal 1 then provides a more effective basis upon which the economic rights of immigrant small-business owners may be protected, by upholding the more reasonable meaning between the parties. Under modern contract law, which more than ever before encourages the consideration of subjective values to promote fair and more equitable results, the drafting enterprise should not be able to bind the immigrant business owner to terms to which she could not reasonably have assented.

In addition to the interpretations approach outlined above, which applies generally to contract formation, special rules have developed to evaluate more explicitly the enforceability of contract terms found in standardized contracts. This assent-based approach, tied more directly to the particularities of form contracts, is embodied in the "reasonable expectations" test:

Although [promisees] typically adhere to standardized agreements and are bound by them without even appearing to know the standard terms in detail, they are not bound to unknown terms which are beyond the range of reasonable expectation."137

Appropriately, the reasonable expectations test has been associated with a philosophical shift from the libertarian individualist vision to a communitarian basis of contract law. ${ }^{138}$ It marks another moment in contract law where social-fairness concerns interrupt freedom-of-contract justifications.

One technique under the reasonable expectations test, developed to release a form recipient from the binding effect of the writing, has been to interpret the language of the form against the drafter. ${ }^{139}$ Implicit in this

137. Darner Motor Sales, Inc. v. Universal Underwriters Ins. Co., 682 P.2d 388, 396 (Ariz. 1984); see also RESTATEMENT (SECOND) OF ConTRACTS § 211 (1981).

138. DiMatteo, supra note 30, at 328-29.

139. See Farnsworth, supra note 105, at 536-37. Another technique developed to refuse to hold a party to a writing has been on the ground that "it was not of a type that would reasonably appear to the recipient to contain the terms of a proposed contract." $I d$. at 536 . In this situation, it is reasoned that such a writing is not an offer at all—instead of a contract on the basis of the form, a contract is "implied by the relationship of the parties in the absence of agreement." Id. Simply put, where a reasonable recipient might not expect the writing to constitute an offer to contract, the written document fails to constitute the contract between the parties. However, by conducting themselves as if they were in a contractual relationship, the parties create an implied contract under which the business owner continues to pay and the vendor delivers. The benefit of this technique lies in the possibility of nullifying a term in the contract limiting the vendor's liability when it performs defieiently.

Unfortunately, the types of writings struck down by courts come mainly in the form of small tickets, passes, and stubs-when it comes to complicated writings "such as [travel] tickets, insurance 
technique is the understanding that a party drafting the contract will inevitably produce a form slanted in that party's favor. ${ }^{140}$ As can be expected, the one-sidedness of form contracts yields unfairness, at least with regards to the bargaining process, since the recipient party has little say in determining and fashioning the final form contract to which it must adhere. Thus, the language of the contract is to be interpreted against the drafter, and standardized or printed terms are given lcss weight than separately negotiated or handwritten and typed terms. ${ }^{141}$ This technique thus provides a powerful means by which a racial-language minority business owner may protect her economic interests. If the business owner disputes a term found in the vendor's form, courts may interpret the term against the vendor and in favor of the owner, who did not have any part in drafting the terms.

Extending this principle against the drafting party, an alternative technique offered under the reasonable expectations test refuses to hold a recipient of a form contract to a certain term on the ground that the term was "not one that an uninitiated reader ought reasonably to have understood to be a part of that offer." 142 This can be satisfied where a term is on the reverse side of the form and the reference to those terms is itself in fine print or otherwise inadequate or where the size of the type and other factors affecting the legibility of the term are "diverted from the diffusion of knowledge to the suppression of it." 143 Additionally, where the terms of the form contract are communicated only after a contract has been made, for example, terms on packaging, on an invoice, or in instructions received after a contract has been made, those terms are often held to be ineffective. ${ }^{144}$ This approach thus places the focus on the drafting party's

policies, and warehouse receipts, [they] ean reasonably be expected to contain contractual terms." $I d$. at 537. This approach in general may not be very amenable to the racial-language business owner because it requires arguing that the writing was not of a type that would reasonably appear to contain the terms of a proposed contract. It seems that unless the business owner can convincingly argue that the writing, with all of its fine print and script, "did not arise to the dignity of a contract" to which she may be bound, a court will disallow the defense. Healy v. N.Y. Cent. \& Hudson River R.R., 138 N.Y.S. 287, 290 (App. Div. 1912).

140. See FARNSWORTH, supra note 105 , at 534.

141. See id. at 540 (noting that statutes such as the Uniform Commercial Code have reinforced these judicial techniques).

142. Id. This technique seems to track the rule which provides an exception for new businesses to an industry: trade usage is employed in contract interpretation as a way of imputing a common knowledge standard onto parties, but excuse is made for businesses new to an industry that have not yet acquired an understanding of such trade usages. See Berwick \& Smith Co. v. Salem Press, Inc., 331 Mass. 196, 198 (1954) ("Where the usage is established the presumption is that the parties contracted with reference to it."); Hurst v. W.J. Lake \& Co., 14l Or. 306, 317-18 (1932) ("We believe that it is safe to assume, in the absence of evidence to the contrary, that when tradesmen employ trade terms they attach to them their trade significance."). But see Flower City Painting Contractors, lnc. v. Gumina Constr. Co., 591 F.2d 162, 165 (2d Cir. 1979) (finding that "[i]t would be unrealistic to hold [neophyte contractor] to a 'reason to know' standard of trade usage").

143. FARNSWORTH, supra note 105 , at 538 (quoting DeLancy v. Insurance Co., 52 N.H. 581, 588 (1873)).

144. Id. 
communication of its terms: with the intent of providing greater protection to the recipient party, this approach emphasizes the availability and accessibility of information by the drafting party of its terms for what is often a "take it or leave it" contract.

A language barrier fits neatly into this analysis. The language employed in communicating information directly relates to the recipient's access to that information. If a court may look to the size of the type and the location of the term language on the form to determine whether the drafting party provided adequate "diffusion of knowledge," there is simply no reason for which the court should not look to the language in which the writing is presented to a non-English speaker. Suppression of knowledge inevitably will be present when the drafting enterprise presents a form document that the recipient party is unable to understand because of a language barrier. Under this technique, then, drafting enterprises may bear the responsibility of providing their form contracts in the Spanish or Asian language of the business owner, since failure to adequately "diffuse" information about its tcrms may limit or bar the enforceability of those tcrms. Outside of the language context, some courts have even placed the burden on the party seeking to enforce the provision to show that "the provisions were explained to the other party and came to his knowledge and there was in fact a real and voluntary meeting of the minds and not merely an objective meeting." 145 A reasonable way in which the drafting enterprise would ensure the racial-language business owner's assent is by explaining the terms with translation. Focusing on the drafting party's communication of its terms may therefore prove to be a powerful safcguard of the business interests of racial-language business owncrs in the face of the vendor's one-sided form contract terms.

\section{IV}

\section{The Coherence And the Equity in Assent-Based Methods}

A quick challenge to the proposition of applying an assent-based approach to the case of a Spanish- or Asian-language-speaking busincss owner may go something like this: if it is commonly accepted that nobody reads these forms to begin with, why should the language of the form matter? Of what detriment is it to the Spanish- or Asian-language speaker that the form is in English if she probably would not read it anyway?

145. Weaver v. Am. Oil Co., 257 lnd. 458, 464 (1971). Although the opinion mainly involves an unconscionability analysis, the court based much of its arguments on the finding that the recipicnt of the form document was a poorly cducated man who should not "be expected to know the law or understand the meaning of technieal terms." Id. at 460 . Perhaps unconscionability presupposes a lack of "real" assent, as opposed to objective assent, which is why the court imposes the burden on the drafting party to manifest "a real and voluntary meeting of the minds and not merely an objective meeting." Id. at 464. 
It is generally true that people, no matter what language they speak, do not read form contracts before signing and assenting to them. In addition, these same individuals may never look at the form again after shaking hands with the salesperson. This presumes, however, a continuing satisfaction with the drafting party's product or service. When the adhering party receives a defective shipment or shoddy services, the first thing that party might do is turn to the form. Whether the parties contract through a language barrier or not, the assent-based rules presented above are always applied in retrospect and after the fact of contract formation. The language in which the form is presented to the adhering party thus always matters, for it largely informs the party of her rights in the face of dissatisfactory and incomplete performance. The form's language creates an opportunity for the party to argue that the terms were not those to which she assented.

In addition, any concerns regarding the costs of translating and providing forms in other languages should not be sufficient to override the social benefits of doing so. ${ }^{146}$ When vendors and suppliers conduct repeated transactions with multiple Spanish- and Asian-language-speaking business owners, the cost of a one-time translation does not diminish the efficiency rationale underlying form contracts. To the contrary, the efficiency objective would be enhanced by placing the duty of translating the form document onto the drafting party-the party with greater resources and in a superior position to understand and to articulate its contract terms - rather than onto the racial-language individuals, who separately will have to take the time and effort to translate and figure out what the drafting party means. The form eventually will have to be translated, but the more socially efficient outcome requires the drafting party to shoulder the responsibility.

Importantly, these objectives remain consistent with the principles of modern contract law and form contract rules. On the one hand, assentbased approaches fit perfectly into the ideal modern contract-law universe, since it recognizes not only the drafting party's capacity but also the raciallanguage minority's individuality and freedom of contract, with the concerns of fairness directing the outcome. On the other hand, the recognition of language and race-based elements in bargaining behavior correlates with the fairness policies behind form contract doctrines. Although form contracts initially coincided with classical contract law's freedom of contract rationale, giving individuals free reign to design contractual obligations according to their needs, it became quickly apparent that unchecked use of

146. On the contrary, some private businesses have recognized the economic benefits of providing forms in other languages and have begun to do so on their own initiative. See, e.g., Michelle Krebs, Whose Words: As the Marketplace Becomes More Diverse, English Isn't Always Enough, Automotive News, Oct. 29, 2001, at 21. 
such adhesive agreements could act as facades for substantive inequality, ${ }^{147}$ since form contracts afford a means by which one party imposes unilateral terms on another "unwitting or even unwilling" party. ${ }^{148}$ The majority of signed form contracts are adhesive, offered on a "take it or leave it" basis, under which the only alternative to eomplete adherence is outright rejection. This leaves the adhering party with little choice. The court in Weaver v. American Oil Co. ${ }^{149}$ noted:

The traditional contract is the result of free bargaining of parties who are brought together by the play of the market, and who meet each other on a footing of approximate economic equality. In such a society there is no danger that freedom of contract will be a threat to the social order as a whole. But in present-day commercial life the standardized mass contract has appeared. It is used primarily by enterprises with strong bargaining power and position. The weaker party, in need of the good or services, is frequently not in a position to shop around for better terms, either because the author of the standard contract has a monopoly (natural or artificial) or because all competitors use the same clauses. ${ }^{150}$

When small-business owners are faced with a form presented by, say, a soda salesman with all the weight of a corporate juggernaut behind him, they have little choice but to sign.

The unfairness of an adhesive contract is compounded by the fact that, unlike the adhering party, the party proffering the form "has had the advantage of time and expert advice in preparing it, almost inevitably producing a form slanted in its favor." 151 Form documents have often been defended with the argument that the form expresses the businessperson's reasonable and necessary terms as informed by experience. However, as Todd Rakoff insightfully points out, the form document is not even a product of the businessman's knowledge. He writes, "Rather, it is the product of the draftman's art. Between the drafting party and the actual draftsman, much knowledge, and much of the sense of fairness, may be lost." ${ }^{152}$ More importantly, the lawyer's goal as draftman is to protect the client as fully as possible from legally enforceable obligations-the lawyer engages in the art of drafting up to the limit allowed by law rather than expressing the real needs of the client's business. ${ }^{153}$ Not surprisingly, the adhering party beeomes responsible under the form contract for more of the risks involved in the transaction. Form contraets vary, but may include disclaimers of

147. See DiMatteo, supra note 30 , at 323.

148. See FARNSWORTH, supra note 105, at 534.

149. 257 Ind. 458 (1971).

150. Id. at 463 (quoting United States v. Bethlehem Steel Corp., 315 U.S. 289, 326 (Frankfurter, J. dissenting)).

151. FARNSWORTH, supra note 105, at 534 .

152. Rakoff, supra note 114, at 1205.

153. Id. at $1205,1222$. 
warranty liability, clauses exculpatory from tort liability, provisions limiting liability to repair and replacement, clauses excluding liability for consequential damages, and provisions limiting notice or the bringing of a suit, to name a few common standardized terms. ${ }^{154}$

The shifting of risks onto the adhering party is troubling in light of the widely accepted assumption that parties, even merchants, do not read standard forms before assenting to them. ${ }^{155}$ Given the length and incomprehensibility of most form documents, eompounded by the use of fine print and convoluted clauses, taking the time and effort to read them defeats the efficiency goals of standardization. ${ }^{156}$ Adhering parties thus are often unfamiliar with the form terms to which they sign. To preserve the efficiency of form contracts while accounting for the potential for abuse in the standardized setting, classical contract's strict "duty to read" doctrine was supplanted by more flexible rules that readily considered barriers to comprehending the form contract. These rules are particularly attuned to engaging in a fairness analysis by examining the role of language in communicating binding obligations, and thus these rules uniquely lend themselves to application in language-based claims brought by racial-language minorities.

The application of assent-based methods to racial-language minorities thus does not radically alter the state of contract law. The only revolutionary feature of applying assent-based methods would be in actually using contract law to counteract the suppression of economic rights and to do so by explicitly recognizing the linguistic inequality, as well as the corresponding racial inequality, between racial-language minorities and Englishspeaking parties in transactional settings. The advantage in applying these assent-based methods to transactions between racial-language minorities and English-speaking parties is that it obliges contract law to affirmatively extend its protective devices to minorities, thereby upholding their legal right to a fair venue for the assertion of their economic rights. By recognizing the language-based claims of racial-language minorities, contract law extends its protections of economic and business rights to all-both to

154. See FARNSWORTH, supra note $105, \S 4.29 \mathrm{~A}$.

155. See Daitom v. Pennwalt Corp., 74l F.2d 1569, 1580 (10th Cir. 1984).

While it is laudable for business persons to read the fine print and boilerplate provisions in exchanged forms, there is nothing ... mandating such careful consideration. The [Uniform Commercial Code dictating form contracts] seems drafted with a recognition of the reality that merchants seldom review exchanged forms with the scrutiny of lawyers.

Id. FULLER \& EISENBERG, supra note 28, at 644 ("There is no more reason to believe that a party has read a standard form if it is sent to him two, three, or even ten times than if it is sent to him once."); ABA Task Force Report on Article 2, 16 DEL. J. CORP. LAW. 981, 1063-64 (1991), exccrpted in FulLer \& EISENBERG, supra note 28, at 624 ("The premise that underlies [the Uniform Commercial Code] section 2-207 is that preprinted boilerplate terms in each party's form are not read. Indeed, they cannot reasonably be expected to be read, by the other party.").

156. FARNSWORTH, supra note $105, \S 4.26$. 
English speakers and to racialized non-English speakers, to those unproblematically "American" as well as to those racializcd as un-American.

\section{CONCLUSION}

With the tremendous expansion of the Latina/o and Asian American communities in the past decade, ${ }^{157}$ their market presence has become a force that cannot be ignored. If left unaddressed, we may see yet another widcning of the disparity in marketplace between the "average" American business and Latina/o- and Asian-owned businesses in the next U.S. economic census. ${ }^{158}$ In addition to protccting the civil and political rights of these immigrant communities, social justice advocates must now and directly confront and ehallenge the hurdles to equal economic participation, which includes English-only policies that permcate the market. As Professor Morant explains:

Basic human liberties of freedom, equality, and justicc cannot be remedicd solely from a political posture. Political and social rights exist symbiotically with economic rights, and they cannot exist as singular entities.... True change in the plight of the disenfranchised can occur only if an effort is made to ensure economic fairncss and aecess. This represents a true transformative agenda which calls for both the elimination of discrimination and equality or fairness in the marketplace. ${ }^{159}$

Now is the time for immigrant minorities to assert their economic rights and to extraet from eontract law what it was not predisposed to give earlier. Any denial of contractual protection to racial-language minorities would be unfair and socially undesirable, considering the potentially discriminatory and prejudicial effects, and unnecessary, since modern contract law promises to more fully acknowledge matters of fairness and equity related to group relations. Racial-language minorities should thus use the rhetoric of their contractual rights to turn society's "institutional logic" against itselfto redeem some of the rhetorical promises and the "self-eongratulations" that seem to thrive in Amcrican politieal discourse. ${ }^{160}$ Dcspite resistance, a progressive move towards addressing the economic rights of raciallanguage minorities by means of contract law should be a crucial and timely eomponent of the social justice agenda. In the struggle for greater

157. See supra note 21.

158. See supra text accompanying notes 20-27.

159. Morant, supra note 38, at 98-99.

160. Crenshaw, supra note 83, at 1365-66. Professor Crenshaw argues for the use of rights rhetoric because "rights are a way of saying that a society is what it is, or that it ought to live up to its deepest commitments." Id. The use of rights rhetoric is effective because "[p]eople can only demand change in ways that reflect the logic of the institutions that they are ehallenging. Demands for change that do not reflect the institutional logic-that is, demands that do not engage and subsequently reinforce the dominant ideology-will probably be ineffective." Id. at 1367 . 
political and social equality, the attainment of liberation from marketplace exploitation and suppression is an imperative, and a more just society requires it. 